INTERNATIONAL MONETARY FUND

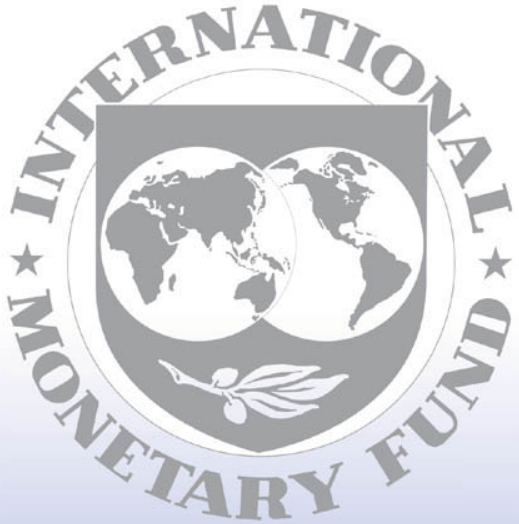

Staff

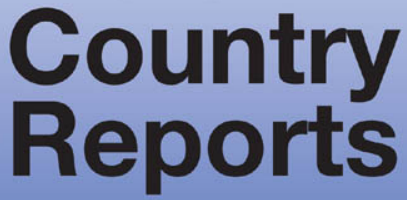




\title{
Republic of Palau: 2008 Article IV Consultation-Staff Report; and Public Information Notice on the Executive Board Discussion for Republic of Palau
}

Under Article IV of the IMF's Articles of Agreement, the IMF holds bilateral discussions with members, usually every year. In the context of the 2007 Article IV consultation with the Republic of Palau, the following documents have been released and are included in this package:

- $\quad$ The staff report for the 2008 Article IV consultation, prepared by a staff team of the IMF, following discussions that ended on March 4, 2008, with the officials of Republic of Palau on economic developments and policies. Based on information available at the time of these discussions, the staff report was completed on April 9, 2008. The views expressed in the staff report are those of the staff team and do not necessarily reflect the views of the Executive Board of the IMF.

- $\quad$ A Public Information Notice (PIN) summarizing the views of the Executive Board as expressed during its April 30, 2008 discussion of the staff report that concluded the Article IV consultation.

The document listed below has been or will be separately released.

Selected Issues Paper and Statistical Appendix

The policy of publication of staff reports and other documents allows for the deletion of market-sensitive information.

To assist the IMF in evaluating the publication policy, reader comments are invited and may be sent by e-mail to publicationpolicy@imf.org.

\author{
Copies of this report are available to the public from \\ International Monetary Fund • Publication Services \\ $70019^{\text {th }}$ Street, N.W. • Washington, D.C. 20431 \\ Telephone: (202) 623-7430 • Telefax: (202) 623-7201 \\ E-mail: publications@imf.org • Internet: http://www.imf.org
}

Price: $\$ 18.00$ a copy

\section{International Monetary Fund \\ Washington, D.C.}


This page intentionally left blank 


\section{INTERNATIONAL MONETARY FUND}

\section{REPUBLIC OF PALAU}

\section{Staff Report for the 2008 Article IV Consultation}

Prepared by the Staff Representatives for the 2008 Consultation with the Republic of Palau

Approved by Steven Dunaway and Anthony Boote

April 9, 2008

Discussions: held in Koror and the capital city, February 21-March 4, 2008. The mission team comprised Ms. Baker (Head), Mr. Lueth (both APD), and Ms. Yang (FIN), with participation of Ms. Manalac (OED), and Mr. Nun (MCM expert). The team met with President Remengesau, Minister of Finance Sadang, Minister of Resources and Development Koshiba, other senior officials, and representatives of the legislature, banking, business and the donor community.

Past surveillance: in concluding the last consultation in February 2006, Executive Directors cautioned against postponing adjustment. They encouraged the authorities to step up efforts toward achieving sustainability, including through targeting an appropriate pace of fiscal consolidation over the medium term and strengthening the foundation for private sector led growth.

Exchange regime: Palau accepted the obligations of Article VIII, Sections 2, 3, and 4 in December 1997, and maintains an exchange system free of restrictions on the making of payments and transfers for current and capital transactions. The U.S. dollar is legal tender.

Statistical issues: economic reporting has deteriorated and constrains effective policy evaluation.

Technical assistance: since 2005, PFTAC has provided assistance in national accounts, bank supervision, tax administration and policy reform, and public financial management. An MCM expert assisted with bank examinations and supervision. 
Executive Summary

I. Background

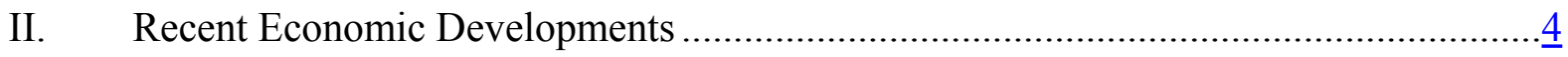

III. Issues for Discussion .................................................................................. 6

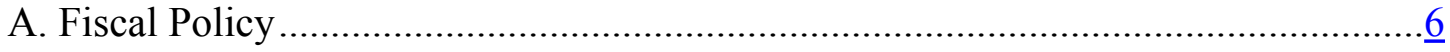

B. Financial Sector ...........................................................................

C. Exchange Rate Regime and Trade Policies ......................................................11

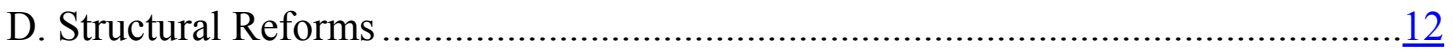

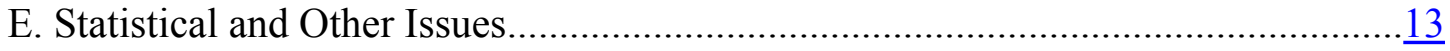

IV. Staff Appraisal ......................................................................................... 14

\section{Boxes}

1. Toward a Sustainable Fiscal Policy .................................................................

2. Republic of Palau: Managing Climate Change.................................................13

Figures

1. Real and External Developments .................................................................... 16

2. Fiscal Developments .............................................................................. 17

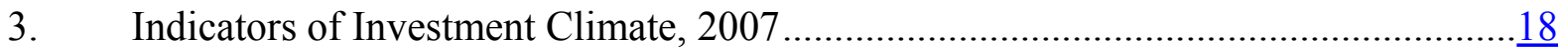

Tables

1. Selected Economic Indicators, 2001/02-2007/08 …..........................................19

2. Balance of Payments, 2000/01-2007/08 ................................................................20

3. National Government Budgetary Operations, 2001/02-2007/08 _............................21

4. Medium-Term Fiscal Scenarios ......................................................................

Appendices

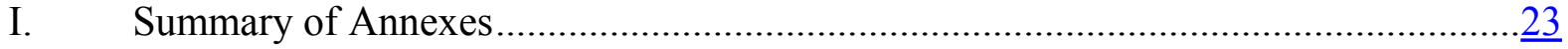




\section{EXECUTIVE SUMMARY}

Background: performance has weakened somewhat since the last consultation. Growth has come down to near its historical average, inflation remains moderate, competitiveness has been preserved and the current account deficit has been stable. However, fiscal performance has been mixed, as revenue weakness has undermined expenditure restraint. The near-term outlook is favorable, with risks skewed to the downside. Palau is at a critical juncture, as term limits imply a sweeping change in leadership following the November elections and the scheduled cessation of Compact grants in 2009 weighs on public finances.

Main Issues: despite relatively high per capita income, self-reliance remains a distant goal. The authorities have long recognized that fiscal policy is not sustainable, but lack of consensus has stalled much of the reform agenda in this small, young nation. In addition, impediments to private sector investment remain. In order to achieve fiscal sustainability and foster long-term growth, structural reforms are required.

Staff's views: the most pressing need is to start on a path to fiscal sustainability. Even in a best-case scenario the required adjustment is formidable. Delays in adjustment not only imply a larger required consolidation down the road, but also increase the likelihood that the Compact Trust Fund will be depleted. Revenue measures should complement progress to date on the expenditure side. In this context, the measures contained in the supplemental budget are welcome. The current exchange rate regime - the U.S. dollar is legal tenderremains appropriate given Palau's small size and close ties to the United States. Looking ahead, establishing a foundation for private sector led growth is key to achieving selfreliance. Policies to encourage high value added tourism and export diversification would help sustain living standards while preserving Palau's pristine environment. Such policies need to be underpinned by a strong legal framework which facilitates contract enforcement and secures property rights. Data provision, while adequate for surveillance, has deteriorated and constrains policy assessment.

Authorities' views: there are hopeful signs that government sponsored reforms will be passed given the increasing recognition that the status quo is not sustainable. An adjustment of about 5 percentage points of GDP over the next 5 years is feasible, assuming that the revenue measures in the supplemental budget are approved. Some frontloading may be possible. They recognize the key role private sector investment can play in fostering growth and aiding information transfer. Progress is being made on the titling of land. However, while several proposals to change and even abolish the foreign investment law have been tabled, there is a lack of consensus on how to make the most of foreign investment and labor while protecting citizen opportunities. Preserving Palau's unique environment is also a top priority. They agree that quality data is required to underpin policy formulation and they continue to work toward producing consistent and reliable data. 


\section{BACKGROUND}

\section{Despite relatively high per capita income, Palau faces challenges common to} island nations, and self-reliance remains a distant goal. Formidable foreign grants have spurred growth, paved the way for increased private investment and contributed to an improved quality of life. Yet, developmental constraints prevail, including vulnerability to external shocks, geographical isolation, a narrow production and export base, a fragile and climate-dependent environment, as well as diseconomies of scale in the provision of public services. In addition, reaching political consensus on key economic and social issues while transitioning from a traditional tribal system to a modern democracy has often proved elusive for the young nation.

2. Palau is now at a critical juncture. Term limits imply that most policymakers will change following the November 2008 general elections, and the scheduled cessation of annual Compact grants in 2009 weighs heavily on the outlook for public finances. ${ }^{1}$ The government has long recognized that current policies are not sustainable, yet lack of consensus and strong vested interests have stalled much of the reform agenda. There are hopeful signs that this may be changing. However, there is a risk that the reform agenda increasingly take a backseat to ongoing discussions with the United States regarding a possible renegotiation of the Compact.

\section{RECENT ECONOMIC DEVELOPMENTS}

Since the last consultation economic performance has softened, but inflation remains in check and the external position is stable. ${ }^{2}$ Revenue weakness has led to a deterioration in the current balance, causing net government wealth to stagnate at about the level of GDP.

3. All indicators point to slowing economic activity. The high growth rates registered in 2004 and 2005 can mostly be attributed to a series of one-off events, such as the hosting of the Pacific Arts Festival, the South Pacific Mini Games, the filming of Survivor Palau and the construction of a new capital on the island of Babeldaob. Since the last consultation, the winding down of two major infrastructure projects, slowing private sector investment and weakening consumer demand have all led growth lower, to near its historical average (Table 1 and Figure 1).

\footnotetext{
${ }^{1}$ Under a 50 year Compact of Free Association with the United States signed in 1994, Palau will receive $\$ 450$ million in "Compact grants" over the first 15 years.

${ }^{2}$ Real activity estimates are based on tourism, investment, employment and other indicators used to extrapolate GDP. Palau has not had official national accounts data since 2001. Balance of payments figures are sketchy.
} 
4. Inflation has receded and the external position is stable. Inflation rose to about $4 \frac{1}{2}$ percent in FY06 - somewhat higher than that of the United States, whose currency Palau uses as legal tender - owing to the impact of rising fuel costs on transportation. In FY07, it came down to around 3-31/2 percent, reflecting a temporary easing in oil prices. The real effective exchange rate has remained broadly stable as dollar weakness has been offset by Palau's inflation differential. The current account deficit (excluding grants) has averaged about 18 percent per year in FY06-FY07, half its FY02 level, despite rising fuel prices (Table 2). ${ }^{3}$

\section{Deteriorating revenue performance has undermined the authorities'} expenditure cutting efforts. Under the Cost Reduction Plan current spending has shown welcome restraint, but domestic revenue declined across the board over the last two years, reflecting weaknesses in tax administration (Table 3 and Figure 2). As a result, the current deficit deteriorated by some 4 percentage points of GDP since FY05, moving the authorities farther from their long-term objective of current balance, and leading to a breach of the budget target in FY07.

6. The government's net financial assets have stagnated at about the level of GDP. External debt stands at 14 percent of GDP. The Compact Trust Fund (CTF) recovered the sharp losses incurred in 2001-02, and stood at \$174 million at end-FY07. The annual average return of the CTF over the last three fiscal years was in line with its benchmark, but this was insufficient to increase the fund's value relative to GDP after deficit financing (Figure 2). ${ }^{4}$

\section{Deposits have partly recovered following the failure of Pacific Savings Bank} (PSB) in late 2006. ${ }^{5}$ However, credit growth has virtually halted as banks have become more cautious in extending credit, and credit quality is low as households are already highly leveraged. Commercial lending rates of the largest banks are at Prime plus 0.5-4 percent.

8. In February 2008 the long delayed amendments to the Financial Institutions Act (FIA) were signed into law, paving the way for more effective bank supervision. These amendments allow the Financial Institutions Commission (FIC) to issue prudential

\footnotetext{
${ }^{3}$ Preliminary import data for FY06 and FY07 show a very large decrease in imports in FY07. A possible explanation is the front-loading of imports for a major investment project which would argue for an averaging of imports over these two years.

${ }^{4}$ The CTF is managed according to international best practice by Merrill Lynch and is among the better governed among Pacific Islands, with regular reporting requirements to its board and congress.

${ }^{5}$ PSB was the second largest bank in Palau with 20 percent of deposits. The bank was placed in receivership in November 2006, and performing assets are in the process of being sold. The process is expected to be wrapped up by end-2008.
} 
regulations without legislative approval; require all banks to have an annual audit; and grant the FIC's staff legal immunity in carrying out official acts. They also empower the FIC to examine for anti-money laundering (AML) issues. Amendments to AML legislation were put in place in late December. ${ }^{6}$

\section{Outlook and risks}

9. The near-term outlook is broadly favorable, with risks tilted to the downside. Growth is projected to moderate further to about 2 percent. Donor-financed capital spending will continue to fund unmet infrastructure needs and tourism would remain strong, while prospects for large private investment projects continue to be clouded by uncertainties surrounding Compact renewal. Downside risks include higher oil prices and the global economic slowdown which may affect tourism. On the upside, a possible expansion of scheduled flights could lead to increased arrivals of high-end tourists.

\section{ISSUES FOR DISCUSSION}

Prudent management of foreign grants has delivered improved infrastructure, growth and a higher standard of living. However, current fiscal policy is not sustainable, even if the Compact were to be renewed. Moreover, the predominance of the public sector in the economy limits growth potential going forward. Thus, the discussions focused on policies and structural reforms aimed at achieving fiscal sustainability and long-term growth-key elements of self-reliance.

\section{A. Fiscal Policy}

10. The authorities recognize that current fiscal policy is not sustainable. Grants amount to nearly $37 \frac{1}{2}$ percent of GDP and tax revenue has been falling. ${ }^{7}$ The staff estimates that even if the Compact were renewed - a best case scenario - current spending would need to be cut by about 10 percentage points of GDP to be sustainable (Scenario B, Box 1; and Table 4). ${ }^{8}$ If the adjustment were to occur gradually, or if the Compact were not renewed, the needed adjustment would be larger. To the extent that domestic revenue can be increased, the

\footnotetext{
${ }^{6}$ The March 2008 joint mission of the IMF and the Asia Pacific Group on Money Laundering found that the amendments strengthen Palau's AML/CFT framework, but several legislative deficiencies remain. Moreover, enforcement is insufficient due to lack of human and financial resources.

${ }^{7}$ Includes both on- and off-budget grants (Table 3); average FY05-FY07.

${ }^{8}$ A Selected Issues paper explores fiscal sustainability using an intertemporal budget framework.
} 


\section{Box 1. Toward a Sustainable Fiscal Policy}

This box explores fiscal sustainability in Palau using the government's intertemporal budget constraint. Four scenarios are presented. The first two scenarios - mainly for illustrative purposes - show the impact on key variables of an immediate adjustment to a sustainable current balance under different assumptions about future Compact grants. The next two scenarios show the impact of a gradual adjustment to a sustainable current balance over 15 years. ${ }^{1 /}$

\section{Immediate Adjustment}

Scenario A: No compact renewal (bold solid line). To achieve sustainability, the current balance would adjust from minus 201/2 percent of GDP in FY07 to minus 5 percent of GDP in FY08, and remain at that level thereafter (Figure 1). In FY08 and FY09, grants would continue after the adjustment had taken place; therefore, Palau would run budget surpluses (Figure 2) and the Compact Trust Fund (CTF) would increase (Figure 3). After FY09 budget deficits would be financed from CTF returns and the CTF would remain constant at about 100 percent of GDP.

Scenario B: Compact renewal (solid line). With an assumed Compact extension until FY24, adjustment to a sustainable current balance would be smaller than under Scenario A ( $10^{1 / 2}$ percentage points of GDP). Overall budget balances would be much higher in the years of additional grant assistance and the assets of the CTF would rise to about 270 percent of GDP.

\section{Gradual Adjustment}

Scenario C: No compact renewal (bold broken line). An adjustment in the current balance of 1.3 percentage points of GDP each year would achieve sustainability by FY21. The gradual adjustment would necessitate withdrawals from the CTF, which would be depleted by FY20.

Scenario D: Compact renewal (broken line). An adjustment of the current balance by 0.9 percentage points of GDP each year would achieve sustainability by FY21. After FY09 assets of the CTF would rise to about 200 percent of GDP in FY24 before stabilizing.

In sum, even with Compact renewal, a sizable fiscal adjustment is required to achieve fiscal sustainability and future Palauans would have to live with current spending that is 10 12 percentage points of GDP lower than today. To the extent that revenue measures are possible, the cuts in spending would be lower. Without Compact renewal, an annual adjustment of 1.3 percentage points of GDP for 15 years would still leave the CTF depleted by FY20.

${ }^{1 /}$ All 4 scenarios assume: Real GDP growth of 3 percent and inflation of 2 percent after FY09. A real rate of return on the Compact trust fund of 6 percent. Capital spending to GDP at historical levels. Under the scenarios that assume no Compact renewal, U.S. Compact grants drop to zero after FY2009, while U.S. non-Compact grants and grants from other countries remain at historical levels ( $14 \frac{1}{2}$ percent of GDP). Under the Compact renewal scenarios, U.S. (current) Compact grants remain at historical levels (12 percent of GDP) for another 15 years and drop to zero after FY2024. In addition, the U.S. is assumed to replenish the Compact Trust Fund to the originally envisaged FY2010 value. Off-budget grants and corresponding capital spending are not considered, as they do not affect the sustainability analysis. 
Box 1. Toward a Sustainable Fiscal Policy (Concluded)
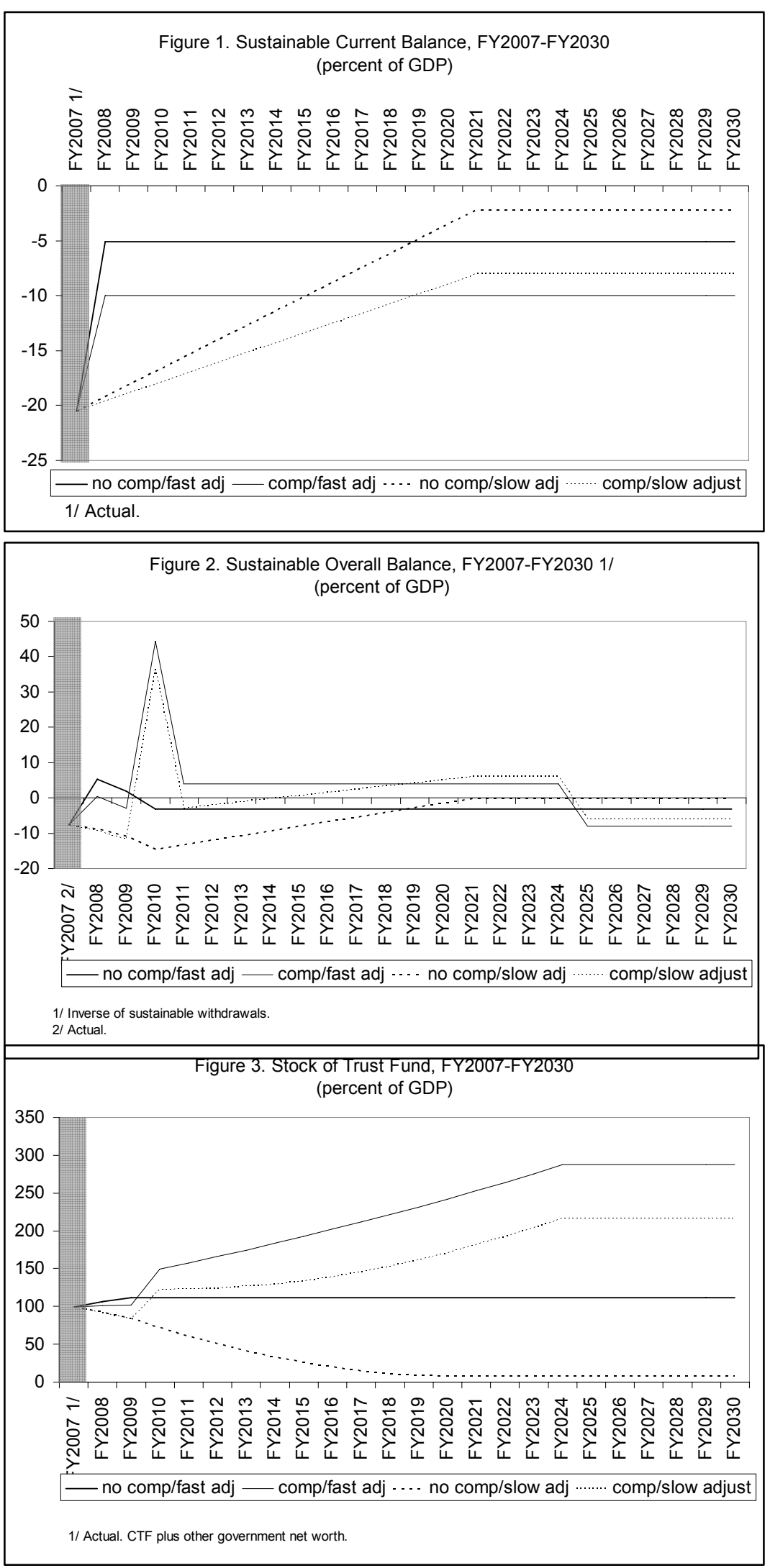
required spending cuts would be smaller. ${ }^{9}$ The authorities noted that these estimates are in line with those of other IFIs and private consultants.

\section{There was broad agreement that an adjustment of the required magnitude could}

not be made immediately, given its impact on public service delivery. The mission recommended an average annual adjustment of $1-1 \frac{1}{3}$ percentage points of GDP over the next 15 years, with about one third of this coming from the revenue side. Without Compact renewal this fiscal policy path would result in a balanced budget by 2020, however, the CTF would be depleted (Scenario C, Box 1). With Compact renewal the trust fund would stabilize at 200 percent of GDP around 2025, and finance a budget deficit of 6 percent of GDP (Scenario D, Box 1). This consolidation path is in line with the authorities' view that they could adjust by about 5 percentage points of GDP over the next 5 years, with some frontloading possible, although they envisioned somewhat more scope for revenue measures.

\section{Recognizing that improvements in tax administration are key to reversing} revenue weakness, the authorities have taken measures. These include suspending business licenses for non-filers, making cash registers mandatory, and conducting a greater variety and audits. The team noted that removing exemptions would likely be the single most effective measure. Additional measures should include establishing a large taxpayer unit, legislating self-assessment, and making audit selection computer-based. The authorities concurred and noted that a large taxpayer unit is being established, but given that the 50 largest tax payers were already paying, they did not expect large revenue gains.

\section{On tax policy, there was shared broad endorsement of the measures in the 1998} report of the Tax Reform Advisory Committee. Eliminating exemptions under the import tax and abolishing refunds under the salaries and wage tax would facilitate administration and increase the tax base. Over the medium term, distortions could be reduced by moving from a gross revenue tax to a net profit tax, by taxing in-kind payments under the salaries and wage tax, and by replacing the import tax with a VAT and excises. ${ }^{10}$ The mission called for a simplified tax system, and cautioned against the introduction of nuisance taxes. ${ }^{11}$ The authorities are looking closely at moving to a net profit tax, but consider a VAT too difficult to administer. Taxation of in-kind payments may be considered further down the road.

\footnotetext{
${ }^{9}$ Inclusion of the unfunded liabilities of the pension fund and fiscal arrears would only serve to increase the required adjustment. The unfunded liabilities of the civil service pension fund exceed 25 percent of GDP, and are poised to increase given its negative annual cash flow. Fiscal arrears, mostly to public enterprises, have declined but remain above $2 \frac{1}{2}$ percent of GDP.

${ }^{10}$ A Selected Issues paper explores options for revenue enhancing tax reform.

${ }^{11}$ The 2007 Tax Review Task Force proposed 8 new taxes, which in staff's view would overburden tax administration and create distortions.
} 


\section{The authorities should build on their success to date in curtailing current}

expenditure. The measures in the Cost Reduction Plan have contributed to a reduction in current spending of 6 percentage points of GDP since FY03. There was agreement that further cost cutting will require some bold steps as maintenance costs of the new capital building and the Compact Road create new spending pressures. The mission recommended to (i) avoid duplication of government offices by closing those in Koror, (ii) commercialize water and sewage services, and (iii) eventually privatize all public utility companies. The authorities maintained that it was never the intention to move public service oriented government offices out of the population center. They are attempting to establish a Maintenance Trust Fund for the up keep of the Compact Road and the capital building; new funds of about 3 million dollars may become available, but given that prospective funds appear insufficient, spending pressures would remain.

\section{There was broad agreement that a reduction in the current deficit of at least} $2 \frac{1}{2}$ percentage points of GDP was feasible in FY08, assuming revenue measures are approved. This would require the government and the legislature to agree on credible measures to underpin the FY08 budget. The enacted changes to the hotel room tax and the fish export tax are insufficient to achieve the revenue target, and forced expenditure cuts could kick in. The authorities are preparing a supplemental budget for the April legislative agenda which includes revenue measures in line with staff recommendations. Proposed measures include eliminating import duty exemptions and moving to a c.i.f. valuation basis; further increasing the specific minimum hotel room tax; unifying the foreign labor fee for Palauan and non-Palauan employers; increasing the currently notional water charge to near cost recovery levels; and commercializing water and sewage services. The latter was considered unlikely to pass this round. Staff's recommendation to raise the fuel excise tax was deemed to impose too large a burden on cash strapped consumers.

\section{B. Financial Sector}

\section{The mission team applauded the recent signing into law of the amendments to} the FIA and encouraged prompt issuance of implementing regulations. The authorities noted that these are being prepared with MCM technical assistance and could be in place by end-summer. The FIC has demonstrated its commitment to a well-regulated financial sector, and the team urged it to take action against the smaller private banks identified as problems. While these banks are not systemic in size, with only about 3 percent of deposits and 7 percent of assets, all three have poor accounting, governance and operational practices which could potentially damage financial sector integrity in the wake of the PSB failure. Early adoption of information sharing agreements with other jurisdictions would enhance cross-border supervisory efforts. Looking forward, off-site supervision would be enhanced through better Call Reports and improved reporting.

17. The FIC stressed that it must be given adequate resources to carry out effective supervision. The mission team commended the FIC for effectively placing PSB in 
receivership despite a vacuous legal framework, repeated efforts by vested interests to delay regulatory forbearance, and limited resources. The FIC noted that some resources will be freed for day-to-day supervision activities as the PSB case winds down. However, the transfer of the Financial Intelligence Unit to FIC - without the required staff and budget to make it operational - places an additional load on already inadequate resources. As provided for under the law, the FIC should formulate and adopt a budget financed by industry charges. This will serve to further increase autonomy by mitigating the risk of legislative underfunding.

\section{Exchange Rate Regime and Trade Policies}

\section{The current exchange rate regime - the U.S. dollar is legal tender-remains} appropriate given Palau's small size and predominance of U.S. grants and trade flows. The authorities stressed that Palau does not have the administrative capacity to conduct an active exchange rate and monetary policy, and its close ties to the U.S. (running through 2044) make dollarization an appropriate framework. In the event of sharply lower grants, a flexible exchange rate could, in principle, redirect domestic demand from tradable to nontradable goods. However, given Palau's narrow production base, the scope for such demand switching seems very limited. Over the near term, external stability is not at risk given the current level of net financial assets; however, over the long term insufficient fiscal adjustment would eventually lead to a depletion of the CTF and possibly mounting external debt.

19. The authorities observed that key indicators point to preserved competitiveness. The real effective exchange rate (REER) has remained broadly stable since 2002, despite a drop in government consumption and a deterioration in the terms of trade. However, the current account excluding grants has improved steadily since FY2000, suggesting that Palau's level of competitiveness is broadly appropriate. Wage pressures are kept at bay through the hiring of foreign labor, and price pressures are held down in part by the open trade regime. ${ }^{12}$ In addition, Palau's main exports - tuna and tourism - tend toward the higher end with lower price elasticity; as a premium and unique dive destination, it does not compete primarily on price. Palau ranks above average in more than half of the World Bank's Doing Business indicators, with room for improvement within the areas of access to credit, protecting investors and enforcing contracts (Figure 3).

\section{High export concentration in water-based tourism exposes the economy to} external shocks. The authorities are looking for areas of possible export diversification. Authorization for investment in two golf courses is in progress, and aquaculture is beginning to take hold. The government has also been approached by firms wishing to carry out oil

\footnotetext{
12 The tariff structure has five nonzero bands, with most imports subject to a 3 percent rate. The unweighted average tariff is just under 3 percent.
} 
exploration and seabed mining activities. The authorities recognize the potential revenue streams such activities could bring, but place a high priority on preserving Palau's pristine environment. Many environmental protection initiatives are in the works in collaboration with other island countries and IFIs, and the government is a key player in the discussions on the impact of climate change (Box 2).

\section{Structural Reforms}

\section{The authorities concurred that the private sector should be the source of} sustainable growth, but noted several obstacles. Tourism and domestic agri- and aquaculture hold the greatest potential. Given Palau's small size, foreign investment could lead to higher growth, broaden the tax base and aid in knowledge transfer. Still, significant impediments to foreign investment remain, and land-use disputes and contract enforcement issues have reportedly delayed foreign investment projects. Moreover, restrictions on foreign investment have led to a proliferation of "front" businesses, operating outside the law. ${ }^{13}$ The mission team emphasized that addressing the outdated legal framework, cumbersome foreign investment regime, and weak property rights should be given priority, as improving the investment climate and removing incentives to circumvent the law are key to private sector led growth.

\section{The authorities lamented that until consensus is reached on key issues, the} legislative agenda to improve the business climate will likely sit idle. They agreed with the thrust of the team's recommendations, ${ }^{14}$ and noted some progress on land titling. ${ }^{15}$

\footnotetext{
${ }^{13}$ The negative list includes tour operators, as well as all retail and wholesale businesses. Foreign investors seeking to operate in these fields must have a local partner, but there is widespread circumvention of the law, with locals (so-called "fronts") selling the use of their name to foreign businesses.

${ }^{14}$ Specific recommendations — in line with the AsDB's 2007 Private Sector Assessment—include: (i) securing property rights by accelerating land titling and dispute resolution, and introducing secured transactions legislation; (ii) harmonizing labor laws to remove the bias against local labor; (iii) reducing the negative list for foreign investment to encourage high value added tourism and eliminate the use of transfer pricing to avoid taxation; and (iv) strengthening the legal framework to ensure contract enforcement.

${ }^{15}$ Under the law, titling should be completed by February 11, 2009. At present, just over 5,100 land title certificates have been granted, of an expected 15,000-20,000 lots. There is a backlog of over 2,000 cases waiting to be heard by the land court. Disputes over ownership or demarcation of boundaries delay about onefourth of all cases.
} 


\section{Box 2. Republic of Palau: Managing Climate Change}

Palau is one of the Pacific island countries most vulnerable to global climate change. Its marine and land biodiversity provide subsistence living as well as a world-renowned diving destination. Recent climate change threatens the survival of its inhabitants and poses immense costs. A 2000 World Bank study for Kiribati places potential economic losses at 17-34 percent of its 1998 GDP by 2050 .

Key effects of climate changes include:

- $\quad$ El Nino/Enso phenomenon. Several months of drought in 1997-1998 resulted in a taro crop loss of $\$ 0.74$ million and fishery production became more volatile.

- $\quad$ Rising sea level and salt water intrusion already damage taro paddies and freshwater resources, and cause extensive soil erosion and loss of coastal infrastructure. The sea level is projected to rise further, as much as 0.09 to 0.88 meters by 2100 , rendering some islands uninhabitable.

- $\quad$ Rising temperatures threaten Palau's ecosystems and lead to the bleaching of coral reefs.

In recognition of this threat, the authorities have actively collaborated with other Pacific island countries and international organizations. In 2000, they conducted climate change assessments as a member of the United Nations Framework Convention on Climate Change (UNFCC). In 2002, Palau acceded to the 1995 Vienna Convention on Protection of the Ozone Layer, and jointly initiated the Micronesian Challenge, whereby it placed 30 percent of its geographic area into marine protected areas (MPAs) or marine managed areas (MMAs). It held a nation-wide workshop in 2006 to explore the impact of changing climate conditions and joined the Alliance of Small Island States (AOSIS) to actively contribute to global climate discussions.

They recognize that the current legal framework is inadequate for doing business. ${ }^{16}$ Yet, on foreign investment, despite the fact that several proposals to change and even abolish the foreign investment law have been tabled, they are being held up by the lack of consensus on how to make the most of foreign investment and labor while protecting citizen opportunities. Much will be decided by the new government.

\section{E. Statistical and Other Issues}

\section{Data are adequate for surveillance but several serious deficiencies remain in} nearly all areas of economic statistics. The authorities willingly share all available data. Notwithstanding, the team expressed concern that data provision has worsened over time. The team strongly urged the authorities to allocate sufficient resources, both human and

\footnotetext{
${ }^{16}$ The current legal framework is based on pre-1953 U.S. Common Law. Key legislative priorities include a uniform commercial code, bankruptcy law, and privacy protection law, as well as arbitration.
} 
financial, to ensuring adequate statistics for policy formulation and assessment. In this regard, a small team of trained staff dedicated to compiling core GDP and balance of payments statistics is key. The authorities agreed that quality statistics are required to underpin policy formulation - they have followed up to the best of their ability on much appreciated TA and continue to work toward producing consistent and reliable numbers. The authorities noted some issues related to the introduction of a new data compilation system in Customs.

\section{STAFF APPRAISAL}

24. Sizable foreign grants continue to support growth and lay the groundwork for private sector development. Prudent management of these funds has preserved their effectiveness, which has led to an improved quality of life. However, since the last consultation economic performance has weakened somewhat. Growth has returned to its historical average as major projects have wound down and inflation is moderate, but fiscal performance has been mixed, with significant expenditure cutting efforts undermined by revenue weakness.

\section{Near-term prospects are broadly favorable but self-reliance remains a distant}

goal. Sustainability depends critically on fiscal consolidation and structural reforms. Uncertainty regarding the future level of grants is heightened by the scheduled cessation of Compact grants in 2009, and private investment faces challenges in securing property rights and contract enforcement.

\section{Current fiscal policy is not sustainable, even if the Compact agreement were} renegotiated. The required adjustment is formidable, and delays in adopting required measures only serve to further increase the adjustment down the road. Therefore, fiscal consolidation should not be postponed while Compact discussions are ongoing. Tax measures will be a key complement to continued progress on the expenditure side, while efforts to strengthen tax administration would help reverse the recent falloff in revenue. Consolidation should be front-loaded, with a medium term pace of adjustment aimed at preserving the trust fund over the long term.

\section{The government and legislature need to agree on credible measures to underpin}

the FY08 budget. The tax measures contained in the supplemental budget are appropriate, and a reduction in the current deficit of at least $2 \frac{1}{2}$ percent of GDP is feasible, assuming the revenue measures are approved. Going forward, distortions could be eliminated by moving from a gross revenue tax to a net profit tax, while privatization of public utilities would eliminate subsidies and strengthen public finances.

28. The staff recognizes the government's commitment to a well regulated financial sector. We commend the FIC for effectively placing the second largest bank in receivership in 2006 despite a vacuous legal framework and limited resources. Moreover, the recent 
signing into law of the amendments to the Financial Institutions Act paves the way for more effective supervision, while the amendments to the AML legislation strengthen the AML framework. The FIC should issue implementing regulations without delay and begin to take action against the three smaller banks identified as problems. Limited supervision and enforcement capacity, lack of resources, and tepid political support are constraints. Capacity building efforts should continue, while use of industry charges, as provided under the law, would ensure adequate funding of supervision and enforcement, and serve to increase autonomy.

\section{Use of the U.S. dollar remains an appropriate monetary and exchange rate}

regime given Palau's small size and continued close ties to the United States over the longer run. Moreover, the benefits of a flexible exchange rate are constrained by Palau's narrow production base and limited scope for demand switching. Competitiveness has been preserved, with the real effective exchange rate broadly stable since 2002 and wage pressures kept at bay through increased hiring of lower-cost foreign labor.

30. Establishing a foundation for private sector led growth is key to achieving selfreliance. Policies to encourage high value added tourism and export diversification would help sustain living standards while preserving Palau's pristine environment. Such policies need to be underpinned by a strong legal framework which facilitates contract enforcement and secures property rights. Foreign investment could play a role by contributing to growth, broadening the tax base and aiding in information transfer. The citizens of Palau will need to come to consensus on the extent of foreign participation in the economy, which will have implications for longer run growth.

\section{Data provision, while adequate for surveillance, has deteriorated and constrains} effective policy evaluation. The authorities willing share all available data. Yet, data deficiencies remain in nearly all areas of economic statistics. Sufficient resources, both human and financial, should be allocated to ensure adequate statistics for policy formulation and assessment.

32. It is recommended that the next Article IV Consultation take place on the 24-month cycle. 
Figure 1. Republic of Palau: Real and External Developments

Higher tourist arrivals have helped sustain growth...

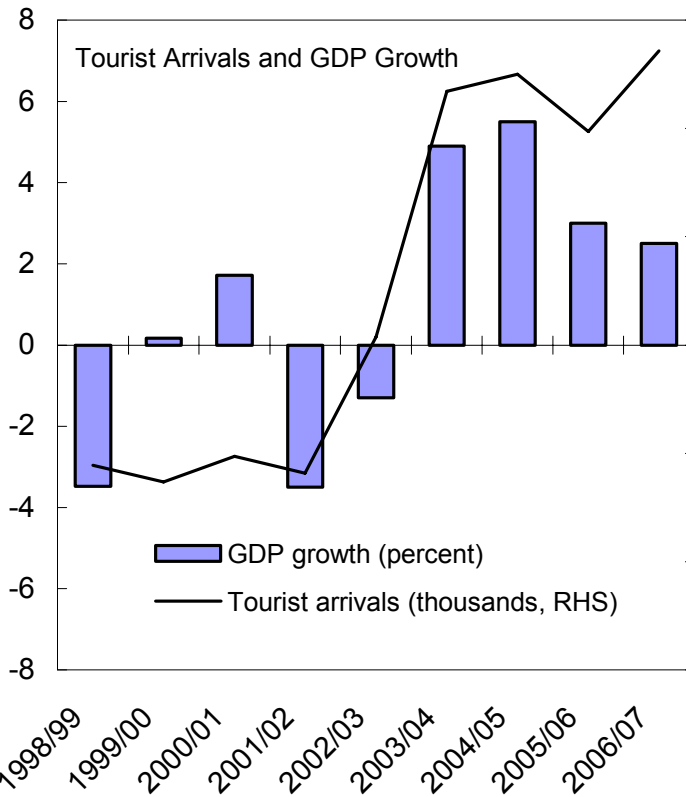

GDP growth is slightly higher than the average for PICs...

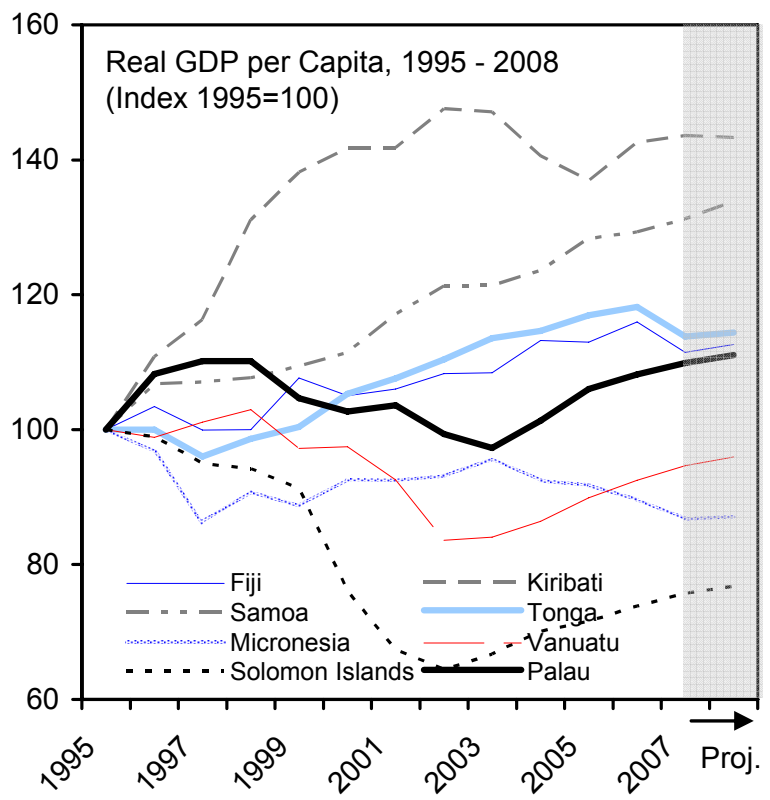

....and higher non-US grants are increasingly financing infrastructure.

90

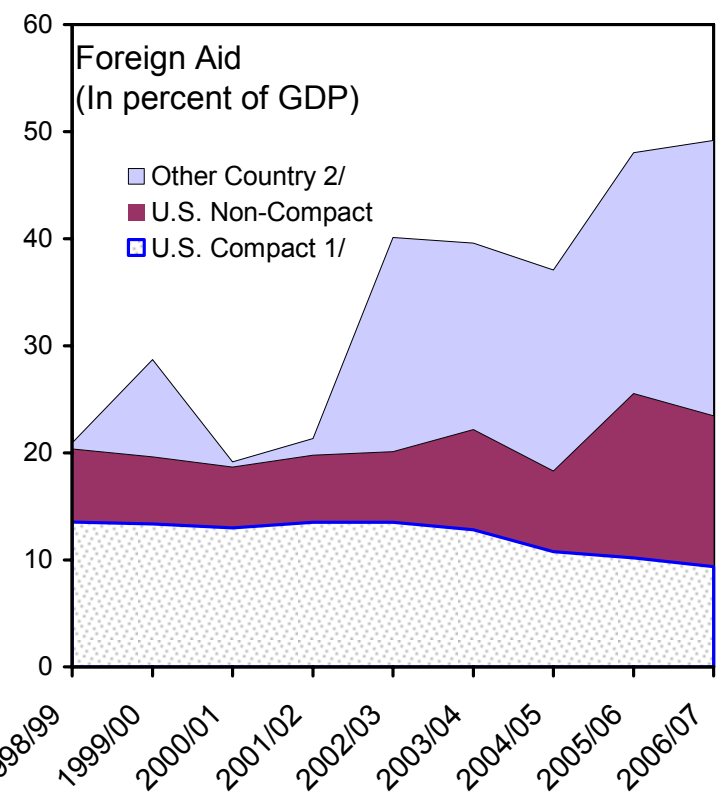

...and the REER has been broadly stable since 2001.

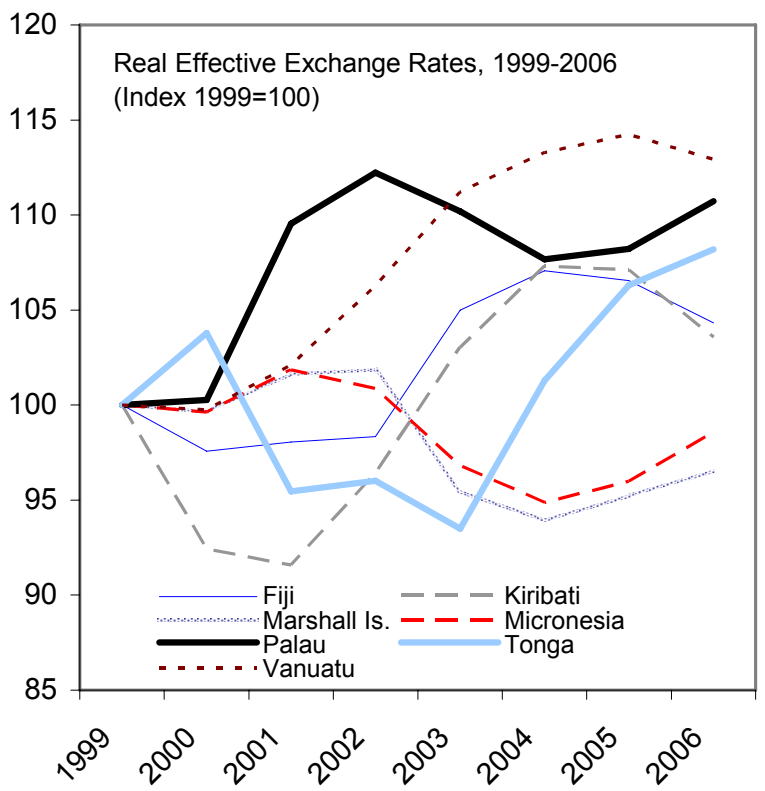

Sources: Country authorities; World Tourist Organization; IMF, Information Notice System; and Fund staff calculations.

1/ Excludes Compact Trust Fund and Compact Road.

2/ Excludes non-budgetary grants from Japan and Taiwan Province of China. 
Figure 2. Republic of Palau: Fiscal Developments

Current spending has steadily declined...

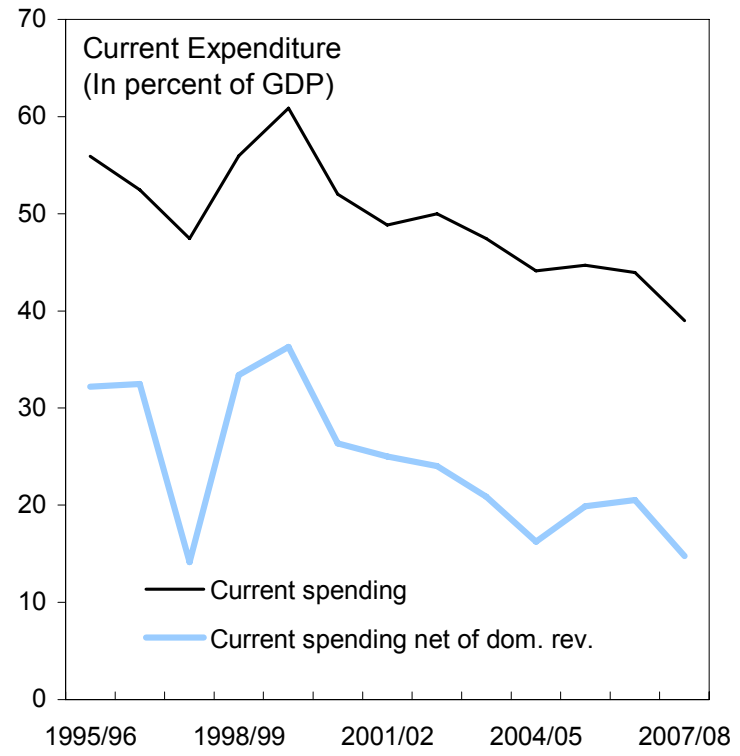

CTF returns are in line with the benchmark...

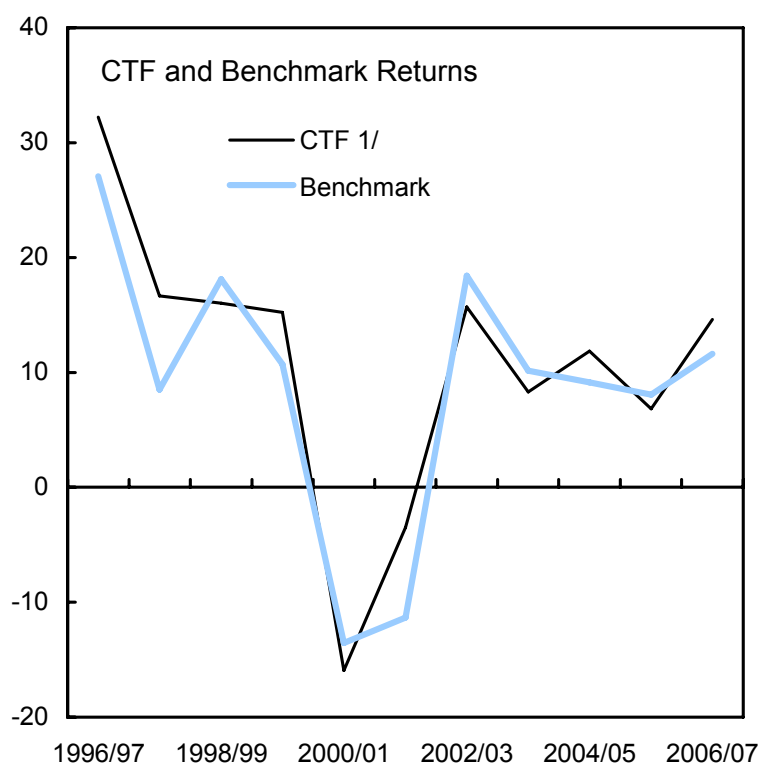

...and government size is similar to other small Pacific islands.

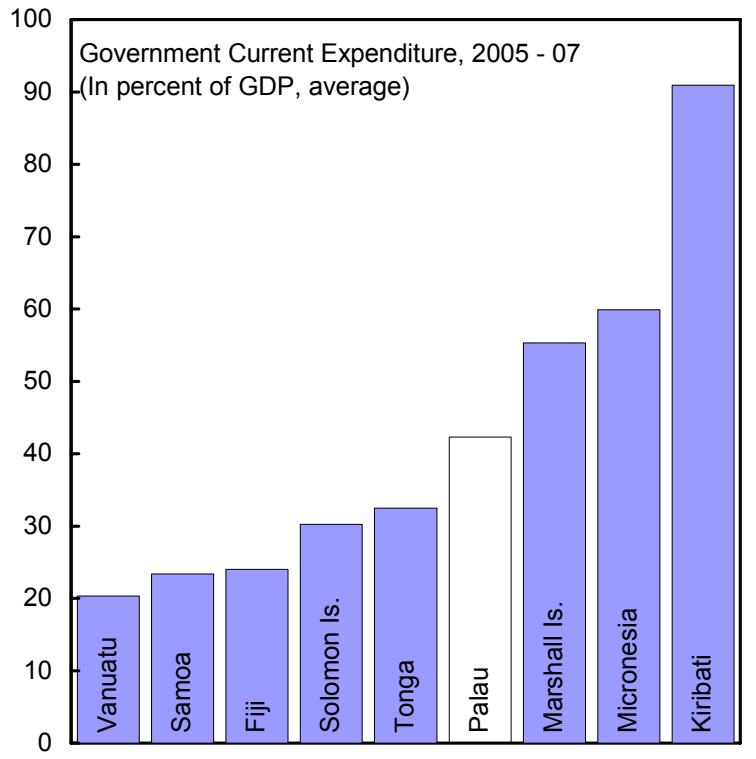

...but net worth has stagnated as share of GDP.

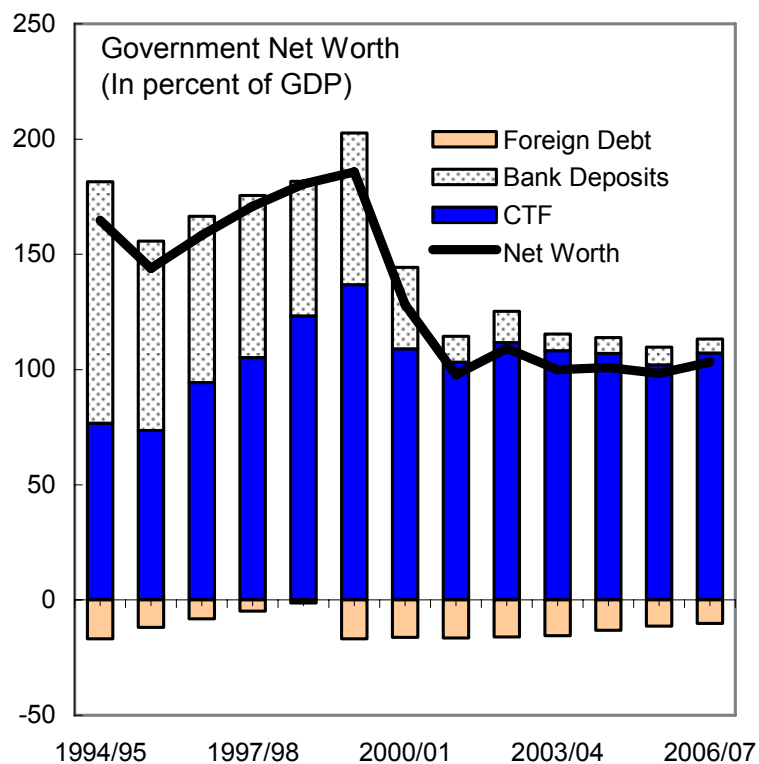

Sources: Country authorities; Datastream; and Fund staff estimates.

1/ Return before fees. Average annual return for CTF was 10.1 and Benchmark was 8.2. 
Figure 3. Republic of Palau: Indicators of Investment Climate, 2007
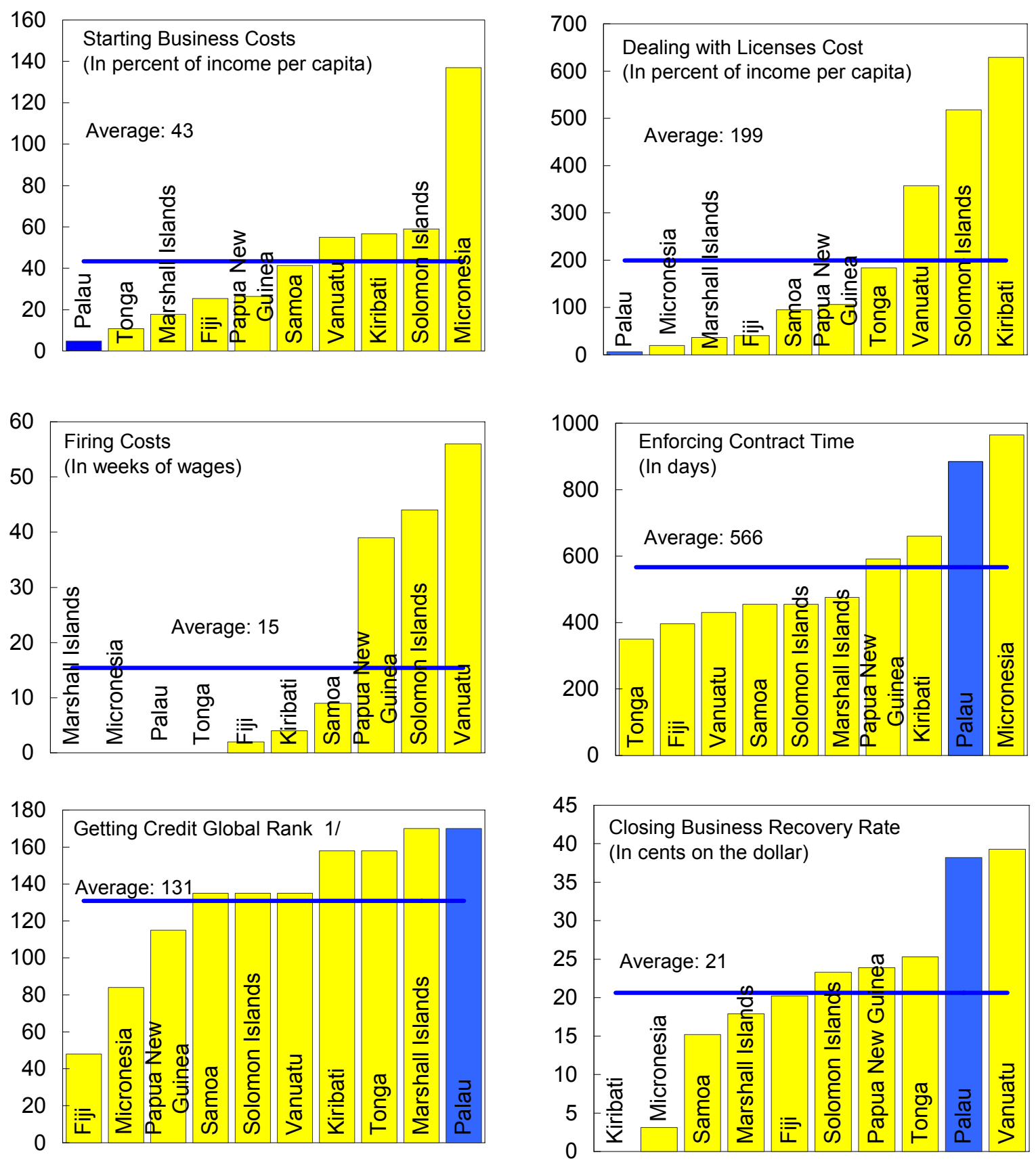

Source: World Bank, Doing Business, 2008.

1/ Ranked among 178 economies; lower number indicates better environment. 
Table 1. Republic of Palau: Selected Economic Indicators, 2001/02-2007/08 1/

\begin{tabular}{|c|c|c|c|c|c|c|c|}
\hline & $2001 / 02$ & $2002 / 03$ & $2003 / 04$ & $2004 / 05$ & $2005 / 06$ & $\begin{array}{r}2006 / 07 \\
\text { Estimate }\end{array}$ & $\begin{array}{r}2007 / 08 \\
\text { Projection }\end{array}$ \\
\hline \multicolumn{8}{|l|}{ Real sector } \\
\hline $\begin{array}{l}\text { Real GDP growth (percent change) } \\
\text { Consumer prices (percent change; period ave.) } \\
\text { Business and tourist arrivals }\end{array}$ & $\begin{array}{r}-3.5 \\
-1.2 \\
48,157\end{array}$ & $\begin{array}{r}-1.3 \\
-0.6 \\
60,734\end{array}$ & $\begin{array}{r}4.9 \\
5.8 \\
83,452\end{array}$ & $\begin{array}{r}5.5 \\
3.2 \\
85,004\end{array}$ & $\begin{array}{r}3.0 \\
4.8 \\
79,720\end{array}$ & $\begin{array}{r}2.5 \\
3.0 \\
87,142\end{array}$ & $\begin{array}{r}2.0 \\
4.2 \\
88,885\end{array}$ \\
\hline Public finance & \multicolumn{7}{|c|}{ (In percent of GDP) } \\
\hline $\begin{array}{l}\text { Central government } \\
\text { Revenue } \\
\text { Domestic revenue } \\
\text { Grants } \\
\text { Expenditures } \\
\text { Current } \\
\text { Capital }\end{array}$ & $\begin{array}{l}42.4 \\
23.8 \\
18.6 \\
66.3 \\
48.9 \\
17.4\end{array}$ & $\begin{array}{l}54.0 \\
26.0 \\
28.1 \\
62.6 \\
50.0 \\
12.6\end{array}$ & $\begin{array}{l}54.1 \\
26.6 \\
27.6 \\
62.7 \\
47.4 \\
15.3\end{array}$ & $\begin{array}{r}52.9 \\
27.9 \\
25.0 \\
53.7 \\
44.1 \\
9.6\end{array}$ & $\begin{array}{l}53.5 \\
24.8 \\
28.6 \\
59.5 \\
44.7 \\
14.8\end{array}$ & $\begin{array}{l}53.1 \\
23.4 \\
29.7 \\
58.0 \\
43.9 \\
14.1\end{array}$ & $\begin{array}{l}46.9 \\
24.2 \\
22.7 \\
51.9 \\
39.0 \\
12.9\end{array}$ \\
\hline $\begin{array}{l}\text { Current balance } 2 / \\
\text { Overall balance (excluding grants) } 3 / \\
\text { Overall balance (including grants) } 3 /\end{array}$ & $\begin{array}{l}-25.0 \\
-47.5 \\
-28.9\end{array}$ & $\begin{array}{r}-24.0 \\
-29.5 \\
-1.5\end{array}$ & $\begin{array}{r}-20.9 \\
-37.3 \\
-9.7\end{array}$ & $\begin{array}{r}-16.2 \\
-27.1 \\
-2.1\end{array}$ & $\begin{array}{r}-19.9 \\
-29.9 \\
-1.2\end{array}$ & $\begin{array}{r}-20.5 \\
-37.3 \\
-7.6\end{array}$ & $\begin{array}{r}-14.8 \\
-27.5 \\
-4.9\end{array}$ \\
\hline \multicolumn{8}{|c|}{ (In millions of U.S. dollars; unless otherwise indicated) } \\
\hline $\begin{array}{l}\text { Compact Trust Fund (CTF) balance } \\
\text { Interest income and capital gains/losses } \\
\text { Investment fees and withdrawals }\end{array}$ & $\begin{array}{r}124.5 \\
-4.7 \\
5.8\end{array}$ & $\begin{array}{r}136.3 \\
19.5 \\
7.7\end{array}$ & $\begin{array}{r}141.6 \\
11.3 \\
6.0\end{array}$ & $\begin{array}{r}152.5 \\
16.8 \\
5.9\end{array}$ & $\begin{array}{r}157.0 \\
10.4 \\
5.9\end{array}$ & $\begin{array}{r}174.0 \\
23.0 \\
6.0\end{array}$ & $\begin{array}{r}174.0 \\
23.0 \\
6.0\end{array}$ \\
\hline Government non-CTF financial assets & 13.7 & 16.4 & 9.5 & 9.8 & 11.8 & 9.9 & $\ldots$ \\
\hline \multicolumn{8}{|l|}{ Balance of payments } \\
\hline $\begin{array}{l}\text { Trade balance } \\
\text { Exports (f.o.b.) } \\
\text { Imports (f.o.b.) } \\
\text { Tourism receipts }\end{array}$ & $\begin{array}{r}-76.4 \\
20.3 \\
-96.7 \\
57.4\end{array}$ & $\begin{array}{r}-79.8 \\
8.4 \\
-88.2 \\
75.6\end{array}$ & $\begin{array}{r}-101.4 \\
5.9 \\
-107.3 \\
96.9\end{array}$ & $\begin{array}{r}-91.8 \\
13.4 \\
-105.2 \\
97.2\end{array}$ & $\begin{array}{r}-101.7 \\
13.6 \\
-115.3 \\
92.9\end{array}$ & $\begin{array}{r}-81.2 \\
10.1 \\
-91.3 \\
99.4\end{array}$ & $\begin{array}{l}\cdots \\
\cdots \\
\cdots \\
\cdots\end{array}$ \\
\hline $\begin{array}{l}\text { Current account balance } \\
\text { Including grants } \\
\text { Excluding grants }\end{array}$ & $\begin{array}{l}-21.2 \\
-41.8\end{array}$ & $\begin{array}{r}-6.0 \\
-27.0\end{array}$ & $\begin{array}{r}-6.8 \\
-30.2\end{array}$ & $\begin{array}{r}-4.7 \\
-25.4\end{array}$ & $\begin{array}{l}-20.8 \\
-42.5\end{array}$ & $\begin{array}{r}9.8 \\
-13.6\end{array}$ & $\begin{array}{l}\ldots \\
\ldots\end{array}$ \\
\hline Overall balance & -34.0 & -4.9 & -8.6 & -4.8 & -5.3 & -5.3 & $\ldots$ \\
\hline $\begin{array}{l}\text { External public debt } 4 / \\
\text { Debt service ratio } 5 /\end{array}$ & $\begin{array}{r}20.0 \\
0.9\end{array}$ & $\begin{array}{r}19.4 \\
1.5\end{array}$ & $\begin{array}{r}20.3 \\
1.8\end{array}$ & $\begin{array}{r}18.6 \\
2.1\end{array}$ & $\begin{array}{r}17.5 \\
1.7\end{array}$ & $\begin{array}{r}22.9 \\
1.6\end{array}$ & $\begin{array}{r}21.5 \\
\ldots\end{array}$ \\
\hline Current account balance & \multicolumn{7}{|c|}{ (In percent of GDP) } \\
\hline $\begin{array}{l}\text { Including grants } \\
\text { Excluding grants }\end{array}$ & $\begin{array}{l}-17.6 \\
-34.6\end{array}$ & $\begin{array}{r}-4.9 \\
-22.1\end{array}$ & $\begin{array}{r}-5.2 \\
-23.1\end{array}$ & $\begin{array}{r}-3.3 \\
-17.8\end{array}$ & $\begin{array}{l}-13.5 \\
-27.6\end{array}$ & $\begin{array}{r}6.0 \\
-8.4\end{array}$ & $\begin{array}{l}\ldots \\
\ldots\end{array}$ \\
\hline External public debt 4 / & 16.6 & 15.9 & 15.5 & 13.1 & 11.4 & 14.1 & 12.5 \\
\hline
\end{tabular}

Sources: Data provided by the Palauan authorities; and Fund staff estimates.

1/ Fiscal Year ending September 30.

2/ Defined as domestic revenue minus current expenditure.

$3 /$ Including errors and omissions.

4/ Does not include public enterprise debt which is not guaranteed by the government.

$5 /$ In percent of exports of goods and nonfactor services. 
Table 2. Republic of Palau: Balance of Payments, 2000/01-2006/07 1/

(In thousands of U.S. dollars)

\begin{tabular}{|c|c|c|c|c|c|c|c|}
\hline & $2000 / 01$ & $2001 / 02$ & $2002 / 03$ & $2003 / 04$ & $2004 / 05$ & $2005 / 06$ & $\begin{array}{r}2006 / 07 \\
\text { Est. }\end{array}$ \\
\hline Trade balance & $-83,302$ & $-76,367$ & $-79,833$ & $-101,398$ & $-91,765$ & $-101,690$ & $-81,206$ \\
\hline Exports, f.o.b. & 16,567 & 20,345 & 8,411 & 5,882 & 13,414 & 13,594 & 10,081 \\
\hline \multirow[t]{2}{*}{ Imports, f.o.b. } & \multirow[t]{2}{*}{$-99,869$} & $-96,712$ & $-88,244$ & $-107,280$ & $-105,179$ & $-115,284$ & $-91,287$ \\
\hline & & 78,684 & 85,322 & 104,562 & 112,272 & 107,966 & 111,324 \\
\hline Services account & 47,889 & 46,005 & 68,239 & 87,698 & 86,539 & 79,594 & 87,262 \\
\hline Receipts & 59,537 & 58,339 & 76,911 & 98,680 & 98,858 & 94,372 & 101,242 \\
\hline Travel & 58,531 & 57,354 & 75,612 & 96,940 & 97,220 & 92,913 & 99,360 \\
\hline Other & 1,006 & 986 & 1,300 & 1,739 & 1,638 & 1,459 & 1,882 \\
\hline Payments & $-11,648$ & $-12,334$ & $-8,672$ & $-10,982$ & $-12,319$ & $-14,778$ & $-13,980$ \\
\hline Transportation & $-10,682$ & $-11,129$ & $-7,697$ & $-9,457$ & $-10,790$ & $-13,184$ & $-12,493$ \\
\hline Passenger's service & $-1,032$ & $-1,302$ & $-1,095$ & $-1,761$ & $-1,766$ & $-1,656$ & $-1,805$ \\
\hline Freight and insurance & $-9,650$ & $-9,827$ & $-6,602$ & $-7,696$ & $-9,024$ & $-11,528$ & $-10,688$ \\
\hline Travel & -966 & $-1,205$ & -975 & $-1,525$ & $-1,529$ & $-1,594$ & $-1,487$ \\
\hline Income & 5,985 & 5,450 & 4,458 & 6,019 & 4,292 & 2,157 & 2,215 \\
\hline Investment income & 5,163 & 4,854 & 3,911 & 5,605 & 3,733 & 445 & 297 \\
\hline Pension Fund Investment Income & 605 & 595 & 566 & 309 & 432 & 840 & 740 \\
\hline Social Security Investment Income & 917 & 713 & 685 & 792 & 792 & 1,529 & 1,798 \\
\hline Income and interest payment & -700 & -712 & -704 & -687 & -665 & -657 & -620 \\
\hline Current transfers & 3,837 & 3,679 & 1,124 & 892 & $-3,799$ & -892 & 1,532 \\
\hline Private & $-17,576$ & $-17,525$ & $-20,366$ & $-23,497$ & $-25,869$ & $-23,367$ & $-22,864$ \\
\hline Inflows & 5,686 & 7,494 & 4,123 & 3,022 & 1,124 & 2,756 & 2,301 \\
\hline Outflows & $-23,262$ & $-25,019$ & $-24,489$ & $-26,519$ & $-26,993$ & $-26,123$ & $-25,165$ \\
\hline Official & 21,413 & 21,204 & 21,490 & 24,389 & 22,070 & 22,475 & 24,396 \\
\hline Business licenses and fees & 1,380 & 1,148 & 1,062 & 1,077 & 1,634 & 1,601 & 1,358 \\
\hline Budget grants & 20,334 & 20,561 & 20,966 & 23,383 & 20,678 & 21,642 & 23,398 \\
\hline Other & -301 & -505 & -538 & -71 & -242 & -768 & -360 \\
\hline $\begin{array}{l}\text { Current account } \\
\text { (includes official grants) }\end{array}$ & $-25,591$ & $-21,233$ & $-6,012$ & $-6,789$ & $-4,733$ & $-20,831$ & 9,804 \\
\hline $\begin{array}{l}\text { Current account } \\
\text { (excludes official grants) }\end{array}$ & $-45,925$ & $-41,794$ & $-26,978$ & $-30,172$ & $-25,411$ & $-42,473$ & $-13,594$ \\
\hline Capital and financial account & 26,616 & 19,582 & 24,752 & 37,001 & 41,639 & 27,483 & 50,597 \\
\hline Public sector & 13,645 & 10,622 & 18,428 & 23,485 & 22,914 & 25,927 & 49,297 \\
\hline Capital grants & 1,064 & 1,888 & 13,243 & 13,882 & 14,979 & 22,424 & 24,800 \\
\hline Off-budget capital grants & 12,581 & 8,734 & 5,756 & 8,746 & 9,578 & 4,646 & 12,140 \\
\hline Gross borrowing 21 & 0 & 0 & 0 & 2,000 & 0 & 0 & 13,500 \\
\hline Loan repayments & 0 & 0 & -571 & $-1,143$ & $-1,643$ & $-1,143$ & $-1,143$ \\
\hline Private sector & 12,972 & 8,960 & 6,324 & 13,516 & 18,725 & 1,556 & 1,300 \\
\hline Foreign direct investment & 12,972 & 8,960 & 6,324 & 13,516 & 18,725 & 1,556 & 1,300 \\
\hline Other private flows/errors and omissions $3 /$ & $-11,554$ & $-32,329$ & $-23,670$ & $-38,763$ & $-41,689$ & $-11,988$ & $-65,737$ \\
\hline Overall balance 4/ & $-10,528$ & $-33,980$ & $-4,931$ & $-8,550$ & $-4,783$ & $-5,336$ & $-5,336$ \\
\hline \multicolumn{8}{|l|}{ Memorandum items: } \\
\hline \multicolumn{8}{|l|}{ Current account as a percent of GDP } \\
\hline Including official grants & -20.7 & -17.6 & -4.9 & -5.2 & -3.3 & -13.5 & 6.0 \\
\hline Excluding official grants & -37.2 & -34.6 & -22.1 & -23.1 & -17.8 & -27.6 & -8.4 \\
\hline Service receipts as a percent of GDP & 48.2 & 48.3 & 63.1 & 75.4 & 69.4 & 61.4 & 62.4 \\
\hline Return on the Compact Trust Fund & $-26,794$ & $-5,543$ & 16,799 & 10,317 & 15,896 & 9,457 & 22,011 \\
\hline
\end{tabular}

Sources: Data provided by the Ministry of Finance and Palau Visitors Authority, Banks; and Fund staff and Ministry of Finance estimates.

1/ Fiscal year ending September 30.

2/ Gross borrowing in FY07 includes a \$7 million soft loan to Palau Public Utility Corporation.

3/ Private bank flows, profit repatriation of so-called front businesses, and errors and omissions.

$4 /$ Increase in the government's gross foreign assets minus return on the Compact Trust Fund, which is not covered in the BOP.

\section{CInternational Monetary Fund. Not for Redistribution}


Table 3. Republic of Palau: National Government Budgetary Operations, 2001/02-2007/08 1/

\begin{tabular}{|c|c|c|c|c|c|c|c|c|c|}
\hline & \multirow[t]{2}{*}{$2001 / 02$} & \multirow[t]{2}{*}{$2002 / 03$} & \multirow[t]{2}{*}{$2003 / 04$} & \multirow[t]{2}{*}{$2004 / 05$} & \multicolumn{2}{|c|}{$2005 / 06$} & \multicolumn{2}{|c|}{$2006 / 07$} & \multirow{2}{*}{$\begin{array}{c}2007 / 08 \\
\text { Budget }\end{array}$} \\
\hline & & & & & Budget & Actual & Budget & Estimate & \\
\hline & \multicolumn{9}{|c|}{ (In thousands of U.S. dollars) } \\
\hline Total revenue and grants & 51,225 & 65,866 & 70,819 & 75,352 & 91,202 & 82,239 & 85,986 & 86,222 & 80,943 \\
\hline Domestic revenue & 28,776 & 31,657 & 34,764 & 39,695 & 37,863 & 38,173 & 39,498 & 38,024 & 41,782 \\
\hline Tax revenue & 22,042 & 22,706 & 26,131 & 30,086 & 29,647 & 29,376 & 31,329 & 29,751 & 34,068 \\
\hline Nontax revenue & 4,520 & 5,713 & 7,622 & 6,276 & 6,771 & 6,641 & 6,736 & 5,825 & 5,857 \\
\hline Local Trust Funds & 2,214 & 3,238 & 1,011 & 1,333 & 1,445 & 2,157 & 1,433 & 2,198 & 1,856 \\
\hline Capital revenue & 0 & 0 & 0 & 2,000 & 0 & 0 & 0 & 250 & 0 \\
\hline Grants & 22,449 & 34,209 & 36,055 & 35,657 & 53,339 & 44,066 & 46,488 & 48,198 & 39,161 \\
\hline Total expenditure & 80,032 & 76,291 & 82,093 & 76,466 & 98,452 & 91,506 & 90,605 & 94,210 & 89,644 \\
\hline Current expenditure & 58,994 & 60,946 & 62,066 & 62,830 & 69,432 & 68,778 & 66,945 & 71,361 & 67,297 \\
\hline Capital expenditure & 21,038 & 15,345 & 20,027 & 13,636 & 29,020 & 22,728 & 23,660 & 22,849 & 22,347 \\
\hline \multicolumn{10}{|l|}{ Errors and omissions, } \\
\hline Accounts Payable/Receivables & $-6,148$ & 8,651 & $-1,467$ & $-1,896$ & 0 & 7,402 & 0 & $-4,310$ & 328 \\
\hline Current balance (excl. grants) & $-30,218$ & $-29,289$ & $-27,302$ & $-23,135$ & $-31,569$ & $-30,604$ & $-27,447$ & $-33,337$ & $-25,515$ \\
\hline Overall balance & $-34,955$ & $-1,774$ & $-12,741$ & $-3,010$ & $-7,250$ & $-1,865$ & $-4,619$ & $-12,298$ & $-8,373$ \\
\hline Financing & 34,955 & 1,774 & 12,741 & 3,010 & 7,250 & 1,865 & 4,619 & 12,298 & 8,373 \\
\hline Net long-term borrowing & 0 & -571 & 857 & $-1,643$ & $-1,143$ & $-1,143$ & 757 & 5,357 & $-2,000$ \\
\hline New borrowing & 0 & 0 & 2,000 & 0 & 0 & 0 & 1,900 & 6,500 & 0 \\
\hline Principal repayments & 0 & 571 & 1,143 & 1,643 & 1,143 & 1,143 & 1,143 & 1,143 & 2,000 \\
\hline Change in NTF assets & 29,955 & $-2,655$ & 6,884 & -347 & 3,393 & $-1,992$ & -138 & 1,941 & 5,373 \\
\hline Withdrawals from Trust Fund & 5,000 & 5,000 & 5,000 & 5,000 & 5,000 & 5,000 & 5,000 & 5,000 & 5,000 \\
\hline & \multicolumn{9}{|c|}{ (in percent of GDP) } \\
\hline Total revenue and grants & 42.4 & 54.0 & 54.1 & 52.9 & 59.3 & 53.5 & 53.0 & 53.1 & 46.9 \\
\hline Domestic revenue & 23.8 & 26.0 & 26.6 & 27.9 & 24.6 & 24.8 & 24.3 & 23.4 & 24.2 \\
\hline Tax revenue & 18.3 & 18.6 & 20.0 & 21.1 & 19.3 & 19.1 & 19.3 & 18.3 & 19.7 \\
\hline Nontax revenue & 3.7 & 4.7 & 5.8 & 4.4 & 4.4 & 4.3 & 4.1 & 3.6 & 3.4 \\
\hline Local Trust Funds & 1.8 & 2.7 & 0.8 & 0.9 & 0.9 & 1.4 & 0.9 & 1.4 & 1.1 \\
\hline Capital revenue & 0.0 & 0.0 & 0.0 & 1.4 & 0.0 & 0.0 & 0.0 & 0.2 & 0.0 \\
\hline Grants & 18.6 & 28.1 & 27.6 & 25.0 & 34.7 & 28.6 & 28.6 & 29.7 & 22.7 \\
\hline Total expenditure & 66.3 & 62.6 & 62.7 & 53.7 & 64.0 & 59.5 & 55.8 & 58.0 & 51.9 \\
\hline Current expenditure & 48.9 & 50.0 & 47.4 & 44.1 & 45.1 & 44.7 & 41.2 & 43.9 & 39.0 \\
\hline Capital expenditure & 17.4 & 12.6 & 15.3 & 9.6 & 18.9 & 14.8 & 14.6 & 14.1 & 12.9 \\
\hline \multicolumn{10}{|l|}{ Errors and omissions, } \\
\hline Accounts Payable/Receivables & -5.1 & 7.1 & -1.1 & -1.3 & 0.0 & 4.8 & 0.0 & -2.7 & 0.2 \\
\hline Current balance (excl. grants) & -25.0 & -24.0 & -20.9 & -16.2 & -20.5 & -19.9 & -16.9 & -20.5 & -14.8 \\
\hline Overall balance & -28.9 & -1.5 & -9.7 & -2.1 & -4.7 & -1.2 & -2.8 & -7.6 & -4.9 \\
\hline \multicolumn{10}{|l|}{ Memorandum items: } \\
\hline GDP (tousand US\$) & 120,755 & 121,909 & 130,852 & 142,461 & 153,818 & 153,818 & 162,370 & 162,370 & 172,574 \\
\hline Off-budget grants (percent of GDP) $2 /$ & 7.2 & 4.7 & 6.7 & 6.7 & $\ldots$ & 3.0 & $\ldots$ & 7.5 & $\ldots$ \\
\hline
\end{tabular}


Table 4. Republic of Palau: Medium-Term Fiscal Scenarios (Percent of GDP, unless otherwise specified)

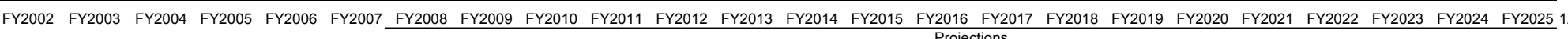

\begin{tabular}{|c|c|c|c|c|c|c|c|c|c|c|c|c|c|c|c|c|c|c|c|c|c|c|c|c|}
\hline \multicolumn{25}{|c|}{ A. No compact renewal; immediate adjustment to generationally equitable fiscal path } \\
\hline Revenue and grants & 42.4 & 54.0 & 54.1 & 52.9 & 53.5 & 53.1 & 46.4 & 43.0 & 38.0 & 38.0 & 38.0 & 38.0 & 38.0 & 38.0 & 38.0 & 38.0 & 38.0 & 38.0 & 38.0 & 38.0 & 38.0 & 38.0 & 38.0 & 38.0 \\
\hline Domestic revenue & & 26.0 & 26.6 & 27.9 & 24.8 & 23.4 & 23.4 & 23.4 & 23.4 & 23.4 & 23.4 & 23.4 & 23.4 & 23.4 & 23.4 & 23.4 & 23.4 & 23.4 & 23.4 & 23.4 & 23.4 & 23.4 & 23.4 & 23.4 \\
\hline Grants & 18.6 & 28.1 & 27.6 & 25.0 & 28.6 & 29.7 & 23.0 & 19.6 & 14.6 & 14.6 & 14.6 & 14.6 & 14.6 & 14.6 & 14.6 & 14.6 & 14.6 & 14.6 & 14.6 & 14.6 & 14.6 & 14.6 & 14.6 & 14.6 \\
\hline Expenditure & 66.3 & 62.6 & 62.7 & 53.7 & 59.5 & 58.0 & 41.1 & 41.1 & 41.1 & 41.1 & 41.1 & 41.1 & 41.1 & 41.1 & 41.1 & 41.1 & 41.1 & 41.1 & 41.1 & 41.1 & 41.1 & 41.1 & 41.1 & 41.1 \\
\hline Expenanture & 0.0 & $\begin{array}{l}02.0 \\
50.0\end{array}$ & 47.4 & 44.1 & 44.7 & $\begin{array}{l}0.0 \\
43.9\end{array}$ & 28.5 & 28.5 & 28.5 & 28.5 & 28.5 & 28.5 & 28.5 & 28.5 & 28.5 & 28.5 & 28.5 & $\begin{array}{l}41.1 \\
28.5\end{array}$ & $\begin{array}{l}41.1 \\
28.5\end{array}$ & 28.5 & 28.5 & 28.5 & 年 & 28.5 \\
\hline Capital & 17.4 & 12.6 & 15.3 & 9.6 & 14.8 & 14.1 & 12.6 & 12.6 & 12.6 & 12.6 & 12.6 & 12.6 & 12.6 & 12.6 & 12.6 & 12.6 & 12.6 & 12.6 & 12.6 & 12.6 & 12.6 & 12.6 & 12.6 & 12.6 \\
\hline Current balance & -25.0 & -24.0 & -20.9 & -16.2 & -19.9 & -20.5 & -5.1 & -5.1 & -5.1 & -5.1 & -5.1 & -5.1 & -5.1 & -5.1 & -5.1 & -5.1 & -5.1 & -5.1 & -5.1 & -5.1 & -5.1 & -5.1 & -5.1 & -5.1 \\
\hline & & & & & & & & 1.9 & -3.1 & -3.1 & 31 & 31 & & -3.1 & -3.1 & -3.1 & & & & & & & & -3.1 \\
\hline CTF stock & 97.9 & 109.3 & 100.0 & 100.9 & 98.4 & 99.2 & $\begin{array}{r}106.0 \\
106.0\end{array}$ & 112.0 & $\begin{array}{r}r .11 \\
112.0\end{array}$ & $\begin{array}{r}-0.1 \\
112.0\end{array}$ & $\begin{array}{r}-312.1 \\
112.0\end{array}$ & $\begin{array}{r}-3.1 \\
112.0\end{array}$ & 112.0 & $\begin{array}{r}-112.0 \\
112.0\end{array}$ & 112.0 & $\begin{array}{r}r-11 \\
112.0\end{array}$ & $\begin{array}{r}-5.1 \\
112.0\end{array}$ & $\begin{array}{r}112.0 \\
112.0\end{array}$ & 112.0 & 112.0 & $\begin{array}{r}r .11 \\
112.0\end{array}$ & 112.0 & $\begin{array}{r}-5.1 \\
112.0\end{array}$ & 112.0 \\
\hline \multicolumn{25}{|c|}{ B. Compact renewal; immediate adjustment to generationally equitable fiscal path } \\
\hline Revenue and grants & 42.4 & 54.0 & 54.1 & 52.9 & 53.5 & 53.1 & 46.4 & 43.0 & 90.4 & 50.0 & 50.0 & 50.0 & 50.0 & 50.0 & 50.0 & 50.0 & 50.0 & 50.0 & 50.0 & 50.0 & 50.0 & 50.0 & 50.0 & 38.0 \\
\hline & & & & & & & & & & & & & & & & & & & & & & & & 23.4 \\
\hline Grants & 18.6 & 28.1 & 27.6 & 25.0 & 28.6 & 29.7 & 23.0 & 19.6 & 67.0 & 26.6 & & $\begin{array}{l}26.4 \\
26.6\end{array}$ & $\begin{array}{l}26.4 \\
26.6\end{array}$ & 26.6 & $\begin{array}{l}26.4 \\
26.6\end{array}$ & $\begin{array}{l}26.4 \\
26.6\end{array}$ & $\begin{array}{l}26.4 \\
26.6\end{array}$ & $\begin{array}{l}20.4 \\
26.6\end{array}$ & $\begin{array}{l}26.4 \\
26.6\end{array}$ & 26.6 & 26.6 & $\begin{array}{l}20.4 \\
26.6\end{array}$ & $\begin{array}{l}20.4 \\
26.6\end{array}$ & $\begin{array}{l}2.4 .6 \\
14.6\end{array}$ \\
\hline Expenditure & 66.3 & 62.6 & 62.7 & 53.7 & 59.5 & 58.0 & 46.0 & 46.0 & 46.0 & 46.0 & 46.0 & 46.0 & 46.0 & 46.0 & 46.0 & 46.0 & 46.0 & 46.0 & 46.0 & 46.0 & 46.0 & 46.0 & 46.0 & 46.0 \\
\hline & & & & & & & & & & 33.4 & 33 & & & & & & & & & & & & & 33.4 \\
\hline Capital & 17.4 & 12.6 & 15.3 & 9.6 & 14.8 & 14.1 & 12.6 & 12.6 & 12.6 & 12.6 & 12.6 & 12.6 & 12.6 & 12.6 & 12.6 & 12.6 & 12.6 & 12.6 & 12.6 & 12.6 & 12.6 & 12.6 & 12.6 & 12.6 \\
\hline Current & -25.0 & -24.0 & -20.9 & -16.2 & -19.9 & -20.5 & -10.0 & -10.0 & -10.0 & -10.0 & -10.0 & -10.0 & -10.0 & -10.0 & -10.0 & -10.0 & -10.0 & -10.0 & -10.0 & -10.0 & -10.0 & -10.0 & -10.0 & -10.0 \\
\hline & & & -9.7 & & -1.2 & & 0.4 & -3.0 & 44.4 & 4.0 & & 4.0 & & 4.0 & & 4.0 & & 4.0 & & & & & 4.0 & -8.0 \\
\hline CTF stock $3 /$ & 97.9 & 109.3 & 100.0 & 100.9 & 98.4 & 99.2 & 101.1 & 102.0 & 149.2 & 157.4 & 165.8 & 174.5 & 183.4 & 192.5 & 201.9 & 211.5 & 221.5 & 231.7 & 242.2 & 253.0 & 264.0 & 275.4 & 287.2 & 287.2 \\
\hline \multicolumn{25}{|c|}{ C. No compact renewal; gradual adjustment to generationally equitable fiscal path } \\
\hline Revenue and grants & 42.4 & 54.0 & 54.1 & 52.9 & 53.5 & 53.1 & 46.7 & 43.6 & 38.9 & 39.2 & 39.5 & 39.8 & 40.1 & 40.4 & 40.7 & 41.0 & 41.3 & 41.6 & 41.9 & 42.2 & 42.2 & 42.2 & 42.2 & 42.2 \\
\hline & & & & & & & & & 24. & 24 & 24 & 25 & 25.5 & 25.8 & 26.1 & 26.4 & & 27.0 & & & & & . & 27.6 \\
\hline Grants & 18.6 & 28.1 & 27.6 & 25.0 & 28.6 & 29.7 & 23.0 & 19.6 & 14.6 & 14.6 & 14.6 & 14.6 & 14.6 & 14.6 & 14.6 & 14.6 & 14.6 & 14.6 & 14.6 & 14.6 & 14.6 & 14.6 & 14.6 & 14.6 \\
\hline Expenditure & 66.3 & 62.6 & 62.7 & 53.7 & 59.5 & 58.0 & 55.5 & 54.5 & 53.5 & 52.5 & 51.5 & 50.5 & 49.4 & 48.4 & 47.4 & 46.4 & 45.4 & 44.4 & 43.4 & 42.4 & 42.4 & 42.4 & 42.4 & 42.4 \\
\hline & & & & & & & & 41.9 & 40.9 & 39 . & 38 & & & & & & & & & 29.8 & 29.8 & 29.8 & 29.8 & 29.8 \\
\hline Capital & 17.4 & 12.6 & 15.3 & 9.6 & 14.8 & 14.1 & 12.6 & 12.6 & 12.6 & 12.6 & 12.6 & 12.6 & 12.6 & 12.6 & 12.6 & 12.6 & 12.6 & 12.6 & 12.6 & 12.6 & 12.6 & 12.6 & 12.6 & 12.6 \\
\hline Current bala & -25.0 & -24.0 & -20.9 & -16.2 & -19.9 & -20.5 & -19.2 & -17.9 & -16.6 & -15.3 & -14.0 & -12.6 & -11.3 & -10.0 & -8.7 & -7.4 & -6.1 & -4.8 & -3.5 & -2.2 & -2.2 & -2.2 & -2.2 & -2.2 \\
\hline & & & & -2.1 & -1.2 & -7.6 & -8.8 & -10.9 & & $\begin{array}{l}-13.3 \\
\end{array}$ & $\begin{array}{l}-12.0 \\
\end{array}$ & $\begin{array}{l}-10.7 \\
\end{array}$ & -9.4 & -8.0 & & & & -2.8 & -1. & -0 & -0 & -0 & -0.2 & -0.2 \\
\hline CTF stock $3 /$ & 97.9 & 109.3 & 100.0 & 100.9 & 98.4 & 99.2 & 91.9 & 84.6 & 72.3 & 61.1 & 50.8 & 41.6 & 33.4 & 26.2 & 20.2 & 15.4 & 11.7 & 9.2 & 8.0 & 8.0 & 8.0 & 8.0 & 8.0 & 8.0 \\
\hline \multicolumn{25}{|c|}{ D. Compact renewal; gradual adjustment to generationally equitable fiscal path } \\
\hline & & & & & & & & & & & & & & & 52.7 & 53.0 & 53.3 & 53.6 & 53.9 & 54.2 & 54.2 & 54.2 & 54.2 & 42.2 \\
\hline & & & & & & 23 & & & & & 24 & & & & & & & & 27 & 27. & 27.6 & & 27.6 & 27.6 \\
\hline Grants & 18.6 & 28.1 & 27.6 & 25.0 & 28.6 & 29.7 & 23.0 & 19.6 & 67.0 & 26.6 & 26.6 & 26.6 & 26.6 & 26.6 & 26.6 & 26.6 & 26.6 & 26.6 & 26.6 & 26.6 & 26.6 & 26.6 & 26.6 & 14.6 \\
\hline & & & & & & & & & & & & & & & & & & & & & & & 48.2 & 48.2 \\
\hline 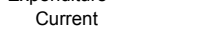 & & & & & & & & & & & & & & & & & & 36 & 36 & 35 & 35.6 & 35.6 & 35.6 & 35.6 \\
\hline Capital & 17.4 & 12.6 & 15.3 & 9.6 & 14.8 & 14.1 & 12.6 & 12.6 & 12.6 & 12.6 & 12.6 & 12.6 & 12.6 & 12.6 & 12.6 & 12.6 & 12.6 & 12.6 & 12.6 & 12.6 & 12.6 & 12.6 & 12.6 & 12.6 \\
\hline $\mathrm{Cu}$ & -25.0 & -24.0 & -20.9 & -16.2 & -19.9 & -20.5 & -19.6 & -18.7 & -17.8 & -16.9 & -16.1 & -15.2 & -14.3 & -13.4 & -12.5 & -11.6 & -10.7 & -9.8 & -8.9 & -8.0 & -8.0 & -8.0 & -8.0 & -8.0 \\
\hline & -28.9 & & & & & & & & & & & & & & & & & & & & & & & -6.0 \\
\hline CTF stock 3 & 97.9 & 109.3 & 100.0 & 100.9 & 98.4 & 99.2 & 91.5 & 83.3 & 122.2 & 122.7 & 124.1 & 126.4 & 129.7 & 134.0 & 139.3 & 145.6 & 152.9 & 161.4 & 171.0 & 181.8 & 192.9 & 204.3 & 216.0 & 216.0 \\
\hline
\end{tabular}

1/ Steady state.

2/ For historical data revenue and expenditures do not add up to the overall balance because of error and omissions.

$3 /$ CTF plus other net worth of the government. 


\section{APPendix I: Palau: Summary of AnNeXes}

\section{Fund Relations}

Palau joined the Fund in December 1997, and has no outstanding purchases or loans. The U.S. dollar is legal tender. The 2005 Article IV consultation was concluded by the Executive Board on February 15, 2006 (IMF Country Report, No. 06/108).

\section{Relations with PFTAC}

Assistance to Palau has been substantial, including 27 advisory missions. Palauan officials have participated in 26 seminars and 10 secondments, mostly in the area of tax administration. PFTAC technical assistance has been provided in the areas of public financial management, tax administration and policy, financial sector regulation and supervision, and economic and financial statistics.

\section{Relations with the World Bank Group}

Palau became a member of the World Bank Group in December 1997. Since that time, the Bank has provided technical assistance in the areas of natural resource management and the health sector. While Palau is IBRD-eligible there are no outstanding loans or credits. The Pacific Regional Strategy directs the Bank's work in the region from 2006-09. It focuses on creating an environment conducive to generating sustainable economic growth and employment, while recognizing the development challenges facing small island economies. The Bank plays a selective role in Palau. It is currently aiding Palau in the valuation of natural resources; providing assistance to the National Oil and Gas Task Force; and, together with the AsDB, supporting the development of a National Development Plan.

\section{Relations with the Asian Development Bank}

Palau joined the AsDB in December 2003. A pre-Country Programming Mission was undertaken in November 2005; Palau is classified as a Pacific developing member country. Current work priorities are guided by the AsDB's Pacific Strategy entitled Priorities of the Poor: A Pacific Strategy for the Asian Development Bank (2005-09). A private sector assessment was carried out in 2007. Current AsDB technical assistance is through Pacific Regional Technical Assistance Activities (RETAs) in the areas of secured transactions legislation and aiding the government in updating its National Development Plan.

\section{Statistical Issues}

Although data provision to the Fund is generally adequate for surveillance, several serious deficiencies remain in nearly all areas of economic statistics. There are presently no official statistical publications at the aggregate level, and data provision has weakened over time. The latest compiled GDP data is from 2001, and monthly data used to estimate GDP (fiscal operations, tourist arrivals, and trade data) are no longer being reported. The authorities' capacity to produce consistent official estimates of the national accounts is very weak, and GDP growth rates reported in the staff report are based on preliminary estimates from sector indicators. Difficulties experienced by Custom's with a new database have impaired import data starting in 2006. 


\section{INTERNATIONAL MONETARY FUND}

REPUBLIC OF PALAU

\section{Staff Report for the 2008 Article IV Consultation-Informational Annex}

Prepared by the Asia and Pacific Department

April 9, 2008

Contents

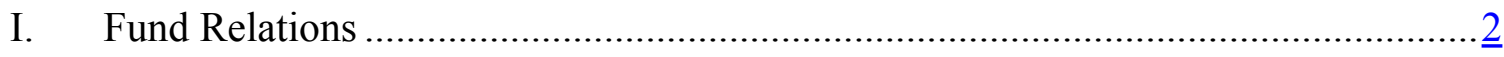

II. Relations with the Pacific Financial Technical Assistance Centre .......................... 4

III. Relations with the World Bank Group................................................................ $\underline{6}$

IV. Relations with the Asian Development Bank ................................................

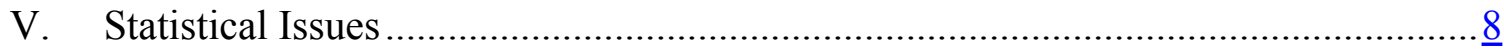




\section{AnNex I. Republic of PALAU: Fund RELATions}

(As of March 25, 2008)

I. Membership Status: Joined December 16, 1997; Article VIII

II. General Resources Account:

SDR Million

3.10

\%Quota

Quota

3.10

100.0

Fund Holdings of Currency

0.00

100.0

Reserve position in Fund

0.03

\section{SDR Department: None}

IV. Outstanding Purchases and Loans: None

V. Financial Arrangements: None

\section{Projected Obligations to Fund: None}

\section{Exchange Arrangement:}

The U.S. dollar is legal tender and the official currency. Palau maintains an exchange system that is free of restrictions on international payments and transfers for current and capital transactions.

\section{Article IV Consultation:}

The first Article IV consultation discussions took place during June 24-July 6, 1999 and the Article IV consultation procedure was completed on November 10, 1999. The last Article IV consultation discussions were held during November 2005. The Executive Board discussed the staff report (SM/06/39) and concluded the consultation on February 15, 2006. Palau is on a 24-month consultation cycle.

\section{Current Financial Arrangement: None}

\section{Technical Assistance:}

FAD/ Preparation of a new tax code, tax and customs $\quad$ October 1998-March 1999 PFTAC administration

Modernization of customs administration

Strengthening tax administration

Tax reform and strengthening tax administration

Public expenditure management
February 2004

July 2005, June 2006

November 2007

January 2007, February 2007 
$\mathrm{FAD} /$

PFTAC Fiscal management

(cont.)

Budget process and formulation

LEG Preparation of a new tax code

Banking legislation (together with MFD)

Anti-money laundering legislation

Joint AML/CFT assessment

MFD/ Establishment of bank supervision functions

$\mathrm{MCM}$

Banking law and regulations (supported by

PFTAC)

Assessing compliance with international supervisory standards and effectiveness of antimoney laundering arrangements in the banking sector

Peripatetic advisor to the Financial Institutions Commission (seven short-term visits to advise on implementation of the Financial Institutions Act)

Bank supervision advisor to review Financial Institutions Act

Bank supervision: issues related to failure of Pacific Savings Bank

Financial sector supervision

Banking supervision advisor to aid with on-site examination

Banking supervision advisor to aid in drafting new banking regulations

STA/ National accounts estimation and GDDS PFTAC
March 2007

January 2007, March 2008

October 1998

April 2002

February 2004

March 2008

October 2000

January 2001

April 2002, August 2004

February 2002-March 2004

April 2005

May 2006, November 2006

April 2007

October 2007-November 2007

February 2008-March 2008

December 2003, April 2004, October 2005, June 2006, April 2007

XI. Resident Representative: None 


\section{AnNex II. Republic of Palau: Support from the PaCific Financial Technical Assistance Centre ${ }^{1}$}

The Centre's assistance since Palau joined the Fund in 1997 has included 27 advisory missions, the participation of officials in seminars (26) and secondments mostly in the tax administration area (10).

\section{Public Financial Management}

Palau did not request explicit TA in this area from 2003 to 2006. Representatives from the Ministry of Finance were invited by PFTAC to join the newly-organized Pacific Financial Managers' Association (PIFMA) in 2006. PFTAC provided assistance in revenue estimation and in developing the Financial Instructions (FIs) in 2007. This was followed by training on the newly developed FIs in early 2008. Discussions are underway now to assist the government in taking forward the medium term budgeting project being discussed with the ADB. Palau has been actively participating in all PIFMA meetings and workshops and hosted the Third PIFMA meeting at Koror in March 2008.

\section{Tax Administration and Policy}

In response to a request received in July 2003, PFTAC reviewed and provided extensive comments on the draft "Registration Corporation Act" and the draft "Reinvestment Incentive Act". In early 2004, a customs administration mission visited Palau to design a strategy and an action plan to modernize the Customs Division. In mid-2005, a tax administration mission visited Palau to review the organizational structure of the Division of Revenue and Taxation, and its operations. In mid-2006, a tax administration mission visited Palau to review the organizational structure of the Division of Revenue and Taxation, and its operations. In 2007, a tax reform and administration mission visited Palau.

\section{Financial Sector Regulation and Supervision}

PFTAC's advisor was involved in two follow-up missions for implementing the Financial Institutions Act (passed in June 2001), as well as to organize the Financial Institutions Commission and the drafting of licensing guidelines. Subsequently, assistance has been provided through the use of peripatetic advisors who have paid a number of visits to Palau. As a result of recommendations by the peripatetic advisors, and likely in response to the recent failure of Pacific Savings Bank, needed amendments to the FIA were approved in February 2008. During 2006 and 2007, the PFTAC advisor was involved in three missions primarily to give guidance and recommendations on receivership supervision matters relating to the failure of Pacific Savings Bank.

\footnotetext{
${ }^{1}$ The Pacific Financial Technical Assistance Centre (PFTAC) in Suva, Fiji is a regional technical assistance institution operated by the IMF with financial support of the Asian Development Bank, Australia, Japan, Korea and New Zealand. The Centre's aim is to build skills and institutional capacity for effective economic and financial management that can be sustained at the national and regional level. Member countries are Cook Islands, Federated States of Micronesia, Fiji, Kiribati, Marshall Islands, Nauru, Niue, Palau, Papua New Guinea, Samoa, Solomon Islands, Tokelau, Tonga, Tuvalu, and Vanuatu.
} 


\section{Economic and Financial Statistics}

The post of Government Statistician has been vacant since late 2002, and two graduate level statisticians are in post at present. A PFTAC mission visited Koror in December 2003 and in April 2004 to assist the authorities in documenting and improving the system of national accounts and with finalization of the GDDS metadata. Subsequently in October 2005, the PFTAC statistics advisor assisted the authorities in revising national accounts for 2001-05. Follow-up missions are expected in the near future, including a PFTAC mission on national accounts statistics being planned for June 2008. 


\section{Annex III. Republic of Palau: Relations with the World Bank Group ${ }^{2}$}

\begin{tabular}{l|l}
\hline Total commitments: & None \\
IFC investments: & None \\
Recent reports: & Pacific Regional Strategy FY2006-09, May 2005. \\
& $\begin{array}{l}\text { Embarking on a Global Voyage: Trade Liberalization and } \\
\text { Complementary Reforms in the Pacific, September 2002. }\end{array}$ \\
\hline
\end{tabular}

1. Palau became a World Bank Group member in December 1997. Since then, the Bank has provided technical assistance in a number of areas, namely oil and gas and natural resource management, and in the health sector.

2. In early-1999, South Pacific Project Facility (SPPF), a small- and medium-enterprise (SME) development initiative of the International Finance Corporation (IFC) provided advisory services to the National Development Bank of Palau, as well as to a number of SME projects in the tourism sector. A diagnostic review of the investment climate was conducted by the Bank Group's Foreign Investment Advisory Services (FIAS) in 1999, and has since undertaken two separate reviews of the new draft foreign investment legislation.

3. The Bank's fifth biennial Regional Economic Report for its Pacific Island member countries, including Palau, was issued in September 2002. The report focused on the efforts of Pacific Island Countries (PICs) to integrate more closely with the global economy. It evaluated the strategy of PICs to enter into a regional trade agreement and analyzed the interaction of trade liberalization with complementary reforms in taxation and the public sector.

4. The Pacific Regional Strategy directs the Bank's work in Palau. It focuses on creating an environment conducive to generating sustainable economic growth and employment, while recognizing that small populations and marked remoteness of the Pacific island countries pose significant development challenges to the region. The country includes technical assistance to the Government to build its capacity in the economic valuation of natural resources and following on from earlier work to aid Palau develop an oil and gas sector, the World Bank is providing assistance to help implement the Road Map for the sector including support for the national Oil and Gas Task force. The World Bank has also been asked to support the development of the National Development Plan alongside the ADB.

5. Palau is an IBRD-eligible country.

\footnotetext{
${ }^{2}$ Prepared by World Bank staff (as of March 2008).
} 


\section{Annex IV. Republic of Palau: Relations With the Asian DeVelopment BanK ${ }^{3}$}

Total Commitments: None.

The Republic of Palau joined the Asian Development Bank on 29 December 2003, as its sixty-third member. While admitted as a regional country, its country classification was to be determined. AsDB prepared a Country Economic Report for Palau and the Development Status and Country Classification of the Republic of Palau which served as the basis for a determination of Palau's development status. On 16 December 2005, the Republic of Palau was re-classified as a Pacific developing member country. A more recent report prepared by AsDB in 2007, Republic of Palau: Achieving Sustainable Development, provided a more detailed overview on Palau's economy.

In order to scope and plan the future programming, a pre-Country Programming Mission was undertaken in November 2005. As one of the Pacific Island economies, Palau is participating in four ongoing Racific Regional Technical Assistance Activities (RETAs) supported by AsDB.

- $\quad$ RETA 6245: Strengthening Pro-Poor Policy in the Pacific.

- $\quad$ RETA 6202: Diagnostic Studies for Secured Transactions Reforms in the Pacific Region.

- $\quad$ RETA 6204: Mainstreaming Environmental Considerations in Economic and Development Planning Processes in Selected Pacific Developing Member Countries.

- $\quad$ RETA 6157: Strengthening Poverty Analysis and Strategies in the Pacific.

There has been no bilateral technical assistance to Palau since they became a member in 2003. Two bilateral technical assistance projects to Palau are scheduled to be delivered:

- $\quad$ TA 4929: Economic and Infrastructure Management (\$1.4 million USD). This TA will assist the government of Palau in its development planning and economic policy and budget management in agreed areas.

- $\quad$ TA 4977: Preparing the Babeldaob Water Supply Project (\$0.875 million USD). This TA will assist the government of Palau to develop a least cost water sector investment plan.

\footnotetext{
${ }^{3}$ Prepared by Fund staff based on information provided by AsDB (as of March 2008).
} 


\section{Annex V. Republic of Palau: Statistical Issues}

Economic and financial data are limited but adequate for surveillance. There are serious shortcomings in the areas of national accounts and balance of payments, which stem mainly from capacity constraints. The Office of Planning and Statistics is responsible for the compilation of national statistics. There are presently no official statistical publications at the aggregate level. PFTAC advisors provided assistance during 2003-2007 in improving the national accounts statistics, and with compiling the GDDS metadata. The long awaited passage of the Statistics Law would further help formalize data collection and reporting.

\section{A. Real sector}

Estimates of the national accounts have only been compiled on a sporadic basis since 1984, and have been unavailable since late 2002. GDP data by economic activity at current prices were compiled by a UNDP consultant, the United Nations Economic and Social Commission for Asia and the Pacific, and under a joint project by the University of Oregon and the U.S. Department of Interior. A UNDP consultant produced a comparable set of GDP estimates for 1992-1999 based on available sector indicators for these years.

The authorities' capacity to produce consistent official estimates of the national accounts is very weak. GDP growth rates reported in the staff report are based on preliminary estimates from sector indicators. A PFTAC advisor who visited Palau in October 2005 pointed to serious deficiencies in source data which the authorities cannot address without more handon technical assistance. Follow-up visits were carried out in 2006 and 2007, but reliable series have not yet been compiled. A new PFTAC Advisor will be providing advice and visiting Palau in the coming months.

A consumer price index has been compiled since 2000 on a quarterly basis.

\section{B. Government finance}

Fiscal data are compiled at both the national and state level as part of their respective annual budgetary processes. The authorities provide fiscal data to APD in a standard Fund-format usable for analysis, however with increasing reporting delays and frequent revisions. Only one person is trained to prepare the data in standard Fund-format. Palau does not report government finance statistics for publication in the Government Finance Statistics Yearbook or in International Financial Statistics. 


\section{Monetary accounts}

Audited balance sheet data are not regularly provided by banks to the authorities as they were not legally required to do so in the past, and hence there is no official compilation of a depository corporations survey. At present, the banks only file quarterly tax forms to the Ministry of Finance. Although most banks have been reporting to the Financial Institutions Commission since 2003, reports are often incomplete and the lack of standardized format and classification guidelines prevent aggregation and meaningful analysis. Lack of data prevents preparation of most financial soundness indicators. An MCM expert is assisting with this task. No monetary data are currently reported to STA for publication in the International Financial Statistics.

\section{Balance of payments}

Balance of payments data compilation remains weak. Estimates have been prepared by the staff based on data provided by the authorities on imports, interest income, official grants, debt service, financial holdings of the government, and rough estimates of exports, services, private transfers and foreign direct investment. Because of Customs' difficulties with a new database, import data starting 2006 has been impaired. Compilation of the balance of payments is further complicated by a lack of commercial banking data due both to the absence of a reporting system for international financial transactions of bank clients, as well as the lack of legal reporting requirement for commercial banks. 


\section{Republic of Palau: Table of Common Indicators Required for Surveillance}

(As of March 31, 2008)

\begin{tabular}{|c|c|c|c|c|c|}
\hline & $\begin{array}{l}\text { Date of latest } \\
\text { observation }\end{array}$ & $\begin{array}{l}\text { Date } \\
\text { received }\end{array}$ & $\begin{array}{c}\text { Frequency } \\
\text { of } \\
\text { Data }^{6}\end{array}$ & $\begin{array}{l}\text { Frequency } \\
\text { of } \\
\text { Reporting }^{6}\end{array}$ & $\begin{array}{c}\text { Frequency } \\
\text { of } \\
\text { publication }\end{array}$ \\
\hline Exchange Rates (U.S. dollar is official currency) & NA & NA & NA & NA & NA \\
\hline International Reserve Assets and Reserve Liabilities of the Monetary Authorities ${ }^{1}$ & NA & NA & NA & NA & NA \\
\hline Reserve/Base Money & NA & NA & NA & NA & NA \\
\hline Broad Money & NA & NA & NA & NA & NA \\
\hline Central Bank Balance Sheet & NA & NA & NA & NA & NA \\
\hline Consolidated Balance Sheet of the Banking System & NA & NA & NA & NA & NA \\
\hline Interest Rates ${ }^{2}$ & $5 / 07$ & $3 / 08$ & A & I & NA \\
\hline Consumer Price Index & $9 / 07$ & $12 / 07$ & Q & I & NA \\
\hline Revenue, Expenditure, Balance and Composition of Financing ${ }^{3}-$ General Government $^{4}$ & $\begin{array}{c}\text { FY99 (State) } \\
\text { FY07 (Funds) }\end{array}$ & $3 / 08$ & A & I & NA \\
\hline Revenue, Expenditure, Balance and Composition of Financing ${ }^{3}-$ Central Government & FY2007 (Prel) & $11 / 07$ & A & I & NA \\
\hline Stocks of Central Government and Central Government-Guaranteed Debt ${ }^{5}$ & FY2007 & $11 / 07$ & A & I & NA \\
\hline External Current Account Balance & FY2007 (Prel) & $11 / 07$ & A & I & NA \\
\hline Exports and Imports of Goods and Services & FY2007 (Prel) & $11 / 07$ & M & I & NA \\
\hline GDP/GNP & FY2001 & NA & NA & NA & NA \\
\hline Gross External Debt & FY2007 (Prel) & $11 / 07$ & A & I & NA \\
\hline
\end{tabular}

${ }^{1}$ Includes reserve assets pledged or otherwise encumbered as well as net derivative positions.

${ }^{2}$ Both market-based and officially-determined, including discount rates, money market rates, rates on treasury bills, notes and bonds.

${ }^{3}$ Foreign, domestic bank, and domestic nonbank financing.

${ }^{4}$ The general government consists of the central government (budgetary funds, extra budgetary funds, and social security funds) and state and local governments.

${ }^{5}$ Including currency and maturity composition.

${ }^{6}$ Daily (D), Weekly (W), Monthly (M), Quarterly (Q), Annually (A), Irregular (I); Not Available (NA) 


\section{INTERNATIONAL MONETARY FUND}

EXTERNAL

Public Information Notice

RELATIONS

DEPARTMENT

Public Information Notice (PIN) No. 08/54

FOR IMMEDIATE RELEASE

May 16, 2008
International Monetary Fund

$70019^{\text {th }}$ Street, NW

Washington, D. C. 20431 USA

\section{IMF Executive Board Concludes 2008 Article IV Consultation with Republic of Palau}

On April 30, 2008, the Executive Board of the International Monetary Fund (IMF) concluded the Article IV consultation with Republic of Palau. ${ }^{1}$

\section{Background}

Over the past two years, economic activity in Palau has slowed, as the winding down of two major infrastructure projects, slowing private sector investment and weakening consumer demand have all led growth lower. However, inflation remains moderate-albeit somewhat higher than that of the United States, whose currency Palau uses as legal tender-with upticks owing to the impact of rising fuel costs on transportation.

Fiscal performance has weakened, with deteriorating revenue performance undermining the authorities' expenditure cutting efforts. The current deficit deteriorated by some 4 percentage points of GDP since FY2005 (October-September), and led to a breach of the budget target in FY2007. External debt is low, standing at 14 percent of GDP. Despite returns on the Compact Trust Fund that are in line with its benchmark, deficit financing has led the government's net financial assets to stagnate at about the level of GDP.

\footnotetext{
${ }^{1}$ Under Article IV of the IMF's Articles of Agreement, the IMF holds bilateral discussions with members, usually every year. A staff team visits the country, collects economic and financial information, and discusses with officials the country's economic developments and policies. On return to headquarters, the staff prepares a report, which forms the basis for discussion by the Executive Board. At the conclusion of the discussion, the Managing Director, as Chairman of the Board, summarizes the views of Executive Directors, and this summary is transmitted to the country's authorities.
} 
Deposits have partly recovered following the failure of Pacific Savings Bank in late 2006. However, credit growth has virtually halted as banks have become more cautious in extending credit, and credit quality is low as households are already highly leveraged.

In February 2008 the long delayed amendments to the Financial Institutions Act (FIA) were signed into law, paving the way for more effective bank supervision. These amendments allow the Financial Institutions Commission (FIC) to issue prudential regulations without legislative approval; require all banks to have an annual audit; and grant the FIC's staff legal immunity in carrying out official acts. They also empower the FIC to examine for anti-money laundering $(\mathrm{AML})$ issues. Amendments strengthening the AML legislation were put in place in late December.

The near-term outlook is broadly favorable, with risks tilted to the downside. Growth is projected to moderate further to about 2 percent as prospects for large private investment projects continue to be clouded by uncertainties surrounding the expiry of Compact grants in late 2009. Downside risks include higher oil prices and the global economic slowdown which may affect tourism. On the upside, a possible expansion of scheduled flights could lead to increased arrivals of high-end tourists.

\section{Executive Board Assessment}

Executive Directors welcomed the authorities' disciplined policies over the past two years, and commended the recent strengthening of financial sector legislation and the continued prudent management of foreign grants, which has preserved the effectiveness of these funds and contributed to an improved quality of life. However, they expressed concern about the impending challenges facing the economy, and encouraged the authorities to build a strong consensus in favor of ambitious fiscal consolidation and an improvement in the business environment to spur private sector led growth.

Directors stressed that sustainability depended critically on fiscal consolidation. They observed that a sizable fiscal adjustment would be required even if Compact grants-which are scheduled for cessation in 2009-are renewed. Directors cautioned against postponing consolidation, as this would only serve to increase future adjustment and raise the likelihood of depleting the trust fund. They encouraged the authorities to implement a front-loaded adjustment followed by a medium term pace of consolidation aimed at safeguarding the trust fund.

Directors applauded the authorities' strong efforts to reduce expenditure, and encouraged them to build on their progress on expenditure compression, especially in light of new spending pressures related to the maintenance of the Compact road and the new capital. At the same time, Directors regretted that these efforts had been undermined by revenue weakness. They 
called for continued strengthening of tax administration, including the removal of exemptions, stressing the need to increase revenue generation. Over the medium term, the authorities should consider a comprehensive overhaul of the tax system, including measures aimed at decreasing distortions and improving efficiency. Commercialization and eventual privatization of public utilities should also be considered to strengthen public finances.

Directors underscored that establishing a foundation for private sector led growth was key to achieving self-reliance. They noted that high value added tourism and export diversification could help sustain growth and living standards. Directors welcomed efforts that have been made in land titling, but noted that a lack of consensus on the role of foreign investment and labor exacerbate investor uncertainty. Regardless of the foreign investment model ultimately adopted, Directors underscored that policies will need to be underpinned by a strong legal framework that facilitates contract enforcement and secures property rights.

Directors commended recent actions by the bank supervisory authority and passage of financial sector legislation, which demonstrated the authorities' commitment to a well regulated financial sector. Prompt issuance of implementing regulations will be key to improving supervision and enforcement. Directors supported the authorities' continued efforts at capacity building, including through additional technical assistance, but emphasized the need for adequate funding. Implementing industry charges, as provided under the law, would also serve to strengthen autonomy by decreasing the risk of legislative underfunding.

Directors supported the continued use of the U.S. dollar as legal tender and the maintenance of an open trade regime. They noted that, over the near term, external stability did not appear to be at risk given current levels of net financial assets, but going forward fiscal consolidation would be required to preserve competitiveness.

Directors encouraged the authorities to improve the coverage, reliability, and timeliness of key economic statistics, through designating adequate human and financial resources while stepping up capacity building efforts through technical assistance. 
Public Information Notices (PINs) form part of the IMF's efforts to promote transparency of the IMF's views and analysis of economic developments and policies. With the consent of the country (or countries) concerned, PINs are issued after Executive Board discussions of Article IV consultations with member countries, of its surveillance of developments at the regional level, of post-program monitoring, and of ex post assessments of member countries with longer-term program engagements. PINs are also issued after Executive Board discussions of general policy matters, unless otherwise decided by the Executive Board in a particular case. The staff report (use the free Adobe Acrobat Reader to view this pdf file) for the 2008 Article IV Consultation with the Republic of Croatia is also available. 
Table 1. Republic of Palau: Selected Economic Indicators, 2001/02-2007/08 1/

\begin{tabular}{|c|c|c|c|c|c|c|c|}
\hline & $2001 / 02$ & $2002 / 03$ & $2003 / 04$ & $2004 / 05$ & $2005 / 06$ & $\begin{array}{r}2006 / 07 \\
\text { Est. }\end{array}$ & $\begin{array}{r}\frac{2007 / 08}{\text { Proj. }} \\
\end{array}$ \\
\hline \multicolumn{8}{|l|}{ Real sector } \\
\hline Real GDP growth (percent change) & -3.5 & -1.3 & 4.9 & 5.5 & 3.0 & 2.5 & 2.0 \\
\hline Consumer prices (percent change; period ave.) & -1.2 & -0.6 & 5.8 & 3.2 & 4.8 & 3.0 & 4.2 \\
\hline Business and Tourist arrivals & 48,157 & 60,734 & 83,452 & 85,004 & 79,720 & 87,142 & 88,885 \\
\hline & \multicolumn{7}{|c|}{ (In percent of GDP) } \\
\hline \multicolumn{8}{|l|}{ Public finance } \\
\hline \multicolumn{8}{|l|}{ Cenral government } \\
\hline Revenue & 43.1 & 42.4 & 54.0 & 54.3 & 53.6 & 61.3 & 61.3 \\
\hline Domestic revenue & 25.7 & 23.8 & 26.0 & 26.8 & 27.6 & 26.7 & 26.7 \\
\hline Grants & 17.3 & 18.6 & 28.1 & 27.6 & 26.0 & 34.5 & 34.5 \\
\hline Expenditures & 64.6 & 66.3 & 62.6 & 61.7 & 54.2 & 61.7 & 61.7 \\
\hline Current & 52.2 & 48.9 & 50.0 & 46.4 & 45.1 & 42.9 & 42.9 \\
\hline Capital & 12.4 & 17.4 & 12.6 & 15.3 & 9.1 & 18.8 & 18.8 \\
\hline Current balance 2/ & -26.4 & -25.1 & -24.0 & -19.7 & -18.9 & -16.2 & -16.2 \\
\hline Overall balance (excluding grants) $3 /$ & -20.3 & -28.3 & -2.4 & -6.9 & -3.9 & -0.4 & -0.4 \\
\hline Uverali Dalance (inciuang granis) & \multicolumn{7}{|c|}{ (In millions of U.S. dollars; unless otherwise indicated) } \\
\hline Compact Trust Fund (CTF) balance & 124.5 & 136.3 & 141.6 & 152.5 & 157.0 & 174.0 & 174.0 \\
\hline Interest income and capital gains/losses & -4.7 & 19.5 & 11.3 & 16.8 & 10.4 & 23.0 & 23.0 \\
\hline Interest fees and withdrawals & 5.8 & 7.7 & 6.0 & 5.9 & 5.9 & 6.0 & 6.0 \\
\hline Government non-CTF financial assets & 13.7 & 16.4 & 9.5 & 9.8 & 11.8 & 9.9 & ... \\
\hline \multicolumn{8}{|l|}{ Balance of payments } \\
\hline Trade balance & -76.4 & -79.8 & -101.4 & -91.8 & -101.7 & -81.2 & $\ldots$ \\
\hline Exports (f.o.b.) & 20.3 & 8.4 & 5.9 & 13.4 & 13.6 & 10.1 & $\ldots$ \\
\hline Imports (f.o.b.) & -96.7 & -88.2 & -107.3 & -105.2 & -115.3 & -91.3 & $\ldots$ \\
\hline Tourism receipts & 57.4 & 75.6 & 96.9 & 97.2 & 92.9 & 99.4 & $\ldots$ \\
\hline \multicolumn{8}{|l|}{ Current account balance } \\
\hline Including grants & -21.2 & -6.0 & -6.8 & -4.7 & -20.8 & 9.8 & $\ldots$ \\
\hline Excluding grants & -41.8 & -27.0 & -30.2 & -25.4 & -42.5 & -13.6 & $\ldots$ \\
\hline Overall balance & -34.0 & -4.9 & -8.6 & -4.8 & -5.3 & -5.3 & ... \\
\hline External public debt $4 /$ & 20.0 & 19.4 & 20.3 & 18.6 & 17.5 & 22.9 & 21.5 \\
\hline Debt service ratio 5/ & 0.9 & 1.5 & 1.8 & 2.1 & 1.7 & 1.6 & ... \\
\hline & \multicolumn{7}{|c|}{ (In percent of GDP) } \\
\hline \multicolumn{8}{|l|}{ Current account balance } \\
\hline Including grants & -17.6 & -4.9 & -5.2 & -3.3 & -13.5 & 6.0 & $\ldots$ \\
\hline Excluding grants & -34.6 & -22.1 & -23.1 & -17.8 & -27.6 & -8.4 & $\ldots$ \\
\hline External public debt $4 /$ & 16.6 & 15.9 & 15.5 & 13.1 & 11.4 & 14.1 & 12.5 \\
\hline
\end{tabular}

Sources: Data provided by the Palauan authorities; and Fund staff estimates.

1/ Fiscal year ending September 30.

2/ Defined as domestic revenue minus current expenditure. 
3/ Including errors and omissions.

4/ Does not include public enterprisse debt which is not guaranteed by the government. $5 /$ In percent of exports of goods and nonfactor services. 